\title{
The Measurement of Tax Elasticity in Sri Lanka : A Time Series Approach ${ }^{1}$
}

\author{
Yuthika Indraratna
}

\begin{abstract}
Since the primary function of a tax system is to generate revenue, the first goal of tax reform must be to ensure that this function is discharged adequately.
\end{abstract}

World Bank (1991)

\begin{abstract}
Revenue mobilisation is an important goal of tax reform. In this regard, tax elasticity - the built-in responsiveness of revenues to changes in income - constitutes an essential ingredient for tax policy formulation. This paper utilises a time series approach to empirically estimate tax elasticities for Sri Lanka for the period 1960-1994. Tax elasticities are computed for income, turnover, excise, import and total taxes on a short run and long run basis for the pre-reform as well as the post-reform periods. All elasticity coefficients reveal a low responsiveness of taxes to income growth with estimates registering less than unity in most cases. The tax buoyancies computed for the same taxes show that tax revenues have been maintained through discretionary measures. (JEL H21, H22)
\end{abstract}

\section{Introduction}

A primary motivation for tax reforms in developing countries has been the need for increased revenues. The need to raise more revenue against the backdrop of high expenditures has taken added importance when compared to other sources of resource mobilisation such as deficit financing and money creation. Tax systems have been revamped and restructured with the objective of maximising tax revenues from the reform process. In this regard, tax elasticity - the responsiveness of tax revenues to income at a given rate structure

1/ This paper forms part of a thesis submitted by Y. Indraratna for the Ph.D. degree at the University of London. I would like to take this opportunity to thank Prof. Richard Disney for his guidance and supervision of this paper and Dr. N. Weerasinghe for valuable suggestions. 
- constitutes an important ingredient of a tax system. An elastic tax system is one in which tax revenues rise proportionately faster than income as income increases. Such a tax system becomes desirable for developing countries in order to provide resources for government expenditures, both for consumption purposes and for financing capital formation. Apart from the need to mobilise resources for revenue purposes, a study of tax elasticity is also important for revenue forecasting purposes, analysing the automatic stabilising properties of a tax system and for examining the progressivity of a tax system. Therefore, an examination of tax elasticity is crucial for tax policy formulation.

This paper measures the elasticity of Sri Lanka's tax system for the period 1960 - 1994 in an attempt to provide some insight as to the revenue responsiveness of Sri Lanka's tax structure. Although a number of methodologies may be employed to determine the elasticity of a tax structure, the data requirements of these techniques necessarily limit their usage in most instances. ${ }^{2}$ This paper attempts to empirically examine tax elasticity in Sri Lanka by resorting to the traditional time series regression approach albeit with improved methodology. The rest of the paper is organised as follows. Section 2 introduces the concept of tax elasticity and provides a definition of tax responsiveness. Section 3 discusses in brief the theoretical framework for the empirical measurement of revenue responsiveness. Section 4 outlines the methodology involved in the empirical estimation of elasticities while providing details of the estimation procedure itself. This section also provides a data description for the time series analysis. Section 5 gives the results of the elasticity estimation. A conclusion follows.

\section{Tax Elasticity}

In the public finance literature, tax elasticity is defined in a number of ways. Elasticity can be generally defined as the change in tax revenue directly arising from a unit change in income. More specifically, elasticity is defined as the ratio of the proportionate change in tax to the proportionate change in income as follows:

$$
\begin{aligned}
E & =\Delta T / T / \Delta Y / Y \\
& =\Delta T / \Delta Y / T / Y
\end{aligned}
$$

$$
\text { where } \begin{aligned}
E & =\text { elasticity } \\
T & =\text { tax payments } \\
Y & =\text { income }
\end{aligned}
$$

\footnotetext{
2/ Johnson and Lambert (1989) point to four methods of measuring empirically income tax revenue responsiveness to growth in incomes; the regression approach, the exact calculation method, the linear pareto model and the simulation method.
} 
In a simple tax function where $T=T(Y)$, equation (1) can also give rise to a definition of elasticity as the ratio of the Marginal Tax Rate (MTR) to the Average Tax Rate (ATR).

$$
E=M T R / A T R
$$

where

$$
\begin{aligned}
M T R & =\Delta T / \Delta Y \\
& =d t / d y \\
& =T^{\prime}(Y)
\end{aligned}
$$

and

$$
A T R=T / Y
$$

ATR as defined above is total tax payments as a proportion of income. MTR can be said to represent the "tax take from a given unit $(£ 1)$ increase in income" (Johnson and Lambert, 1989). ${ }^{3}$ In other words, it is the rate of tax applied on an incremental unit of income.

\subsection{Aggregating Tax Elasticities}

A widely used measure of tax elasticity is the definition of tax elasticity as the weighted average of the sum of the elasticities of separate taxes that often have widely divergent responses to changes in income (Mansfield, 1972). Overall tax elasticity therefore is determined through a weighted sum of elasticities of individual taxes as follows:

$$
E_{T Y}=\frac{T_{1}}{T_{t}}\left[\left(\frac{\Delta T_{1}}{\Delta Y} \frac{Y}{T_{1}}\right)+\ldots \ldots . \frac{T_{k}}{T_{t}}\left(\frac{\Delta T_{k}}{\Delta Y} \frac{Y}{T_{k}}\right)+\ldots \ldots . \frac{T_{n}}{T_{t}}\left(\frac{\Delta T_{n}}{\Delta Y} \frac{Y}{T_{n}}\right)\right]
$$

where

$$
\begin{aligned}
\mathrm{E}_{T Y} & =\text { elasticity of total tax revenue to income } \\
\mathrm{T}_{t} & =\text { total tax revenue } \\
\mathrm{T}_{k}, \mathrm{~T}_{n} & =\text { tax revenue from } k^{\text {th }} \text { and } n^{\text {th }} \text { taxes in a system of } \mathrm{n} \text { taxes } \\
Y & =\text { income }
\end{aligned}
$$

3/ MTR in this paper corresponds to the Effective Marginal Rate (EMR) measure used by Johnson and Lambert (1989) and Lambert (1993). 
The above definition of tax elasticity is based on the definition of the elasticity of individual taxes which can be separated into two components tax to base elasticity and base to income elasticity as follows:

$$
E_{t k y}=\left(\frac{\Delta T_{k}}{\Delta B_{k}} \frac{B_{k}}{T_{k}}\right)\left(\frac{\Delta B_{k}}{\Delta Y} \frac{Y}{B_{k}}\right)
$$

where

$$
\mathrm{B}_{k}=\text { tax base of the } k^{\text {th }} \text { tax }
$$

and the bracketed expression on the left hand side of equation (6) constitutes the tax to base elasticity of the $k^{\text {th }}$ tax and the bracketed expression on the right hand side represents the base to income elasticity of the $k^{\text {th }}$ tax. From equation (6) the elasticity of total revenue to income can be shown to depend on the product of the tax to base and base to income elasticities of individual taxes weighted by the importance of the individual taxes in the tax structure as follows:

$$
E_{T t y}=\frac{T_{1}}{T_{t}}\left[\left(\frac{\Delta T_{1}}{\Delta B_{1}} \frac{B_{1}}{T_{1}}\right)\left(\frac{\Delta B_{1}}{\Delta Y_{1}} \frac{Y_{1}}{B_{1}}\right)\right]+\ldots \ldots \ldots \ldots \frac{T_{n}}{T_{1}}\left[\left(\frac{\Delta T_{n}}{\Delta B_{n}} \frac{B_{n}}{T_{n}}\right)\left(\frac{\Delta B_{n}}{\Delta Y} \frac{Y}{B_{n}}\right)\right]
$$

An advantage of using such a definition is the ability to identify factors responsible for rapid or lagged revenue growth. Factors that affect tax to base elasticity such as tax rates, exemptions and improvements in tax administration are within the control of the fiscal authorities thereby making this measure important for policy purposes. Base to income elasticity on the other hand is determined largely by the way in which the economic structure responds to growth.

It may be appropriate at this juncture to highlight the distinction between two measures of revenue responsiveness, the concepts of elasticity and buoyancy. Tax elasticity measures the built-in response of revenues to changes in income, while tax buoyancy quantifies the total change in revenue due to changes in income. Tax elasticity in other words, measures the responsiveness of tax revenue excluding the effect of discretionary changes taken by authorities to maintain short term revenue objectives. Elasticity compares the growth in tax revenue with that of GDP on the assumption that a particular tax structure prevails throughout the period under study. In other words, tax elasticity captures the responsiveness of tax revenue to changes in income assuming an 
unchanged tax structure while buoyancy measures the responsiveness of revenue to a changed tax system. An elasticity coefficient of one would indicate a similar growth for both revenue and GDP while a coefficient less than one would show lagged revenue growth compared to GDP growth. An elasticity of more than one would indicate revenue growth exceeding GDP growth. Likewise, a buoyancy of one would indicate a revenue growth in line with GDP growth. A buoyancy of less than one would be indicative of a growth in revenue which is less than proportionate to GDP growth while a buoyancy of more than one would show a more than proportionate growth in revenue.

Tax elasticity and buoyancy constitute only two measures encountered in the public finance literature to quantify tax revenue responsiveness to growth in incomes. The other widely used measures are the Average Rate Responsiveness (ARR) measure, the Gross Earnings Deflator (GED) and the Marginal Rate Responsiveness (MRR) measure [(Johnson and Lambert, 1989) (Lambert, 1993)].

\section{Measuring Revenue Responsiveness Empirically}

Johnson and Lambert (1989) point to four methods of measuring empirically income tax revenue responsiveness to growth in income. These comprise the Regression approach [(Prest 1962), (Tanzi 1969,1976), (Jayasundara 1989), (Ram 1991)], the Exact Calculation method [(Hutton and Lambert 1980), (Fries, Hutton and Lambert 1982)], the Linear Pareto model (Hutton and Lambert 1982a), and the Simulation method [(Dorrington 1974), (Hutton and Lambert 1982b), (Caminada and Goudswaard 1996)]. However, other methodologies have also been utilised to measure elasticity. Among contributors to other approaches have been Choudhry (1979) where a divisia index approach based on a productivity concept has been used, and Creedy and Gemmel (1982) who have utilised a tax model to examine the elasticity of the UK income tax. Empirically, the regression approach has been the most extensively adopted methodology to examine tax elasticities. As this paper also utilises a time series regression analysis to estimate elasticities, discussion will now focus upon the regression methodology.

\subsection{Regression Methodology}

A typical log linear specification of an equation of this form is:

$$
\ln T_{i}=a+b \ln X_{i}+e_{i}
$$

where $\quad \mathrm{T}_{i}=$ tax revenue from $i^{\text {th }}$ observation

$\mathrm{X}_{i}=\operatorname{tax}$ base of $i^{\text {th }}$ observation 
Elasticity in this case is measured by the coefficient $b$. The regression method is based on the functional form

$$
T=A x^{b}
$$

where it is assumed that when incomes change by a certain factor $k$, tax liabilities also change by $k^{b}$ which leads to an increase in tax revenues. The assumption of constant proportionality between $t$ and $x^{b}$ in this method does not take into account a change in the distribution of income in time series analyses, although additional regressors might be added to capture these and other effects.

A tax system may change due to discretionary measures such as rate revisions, expansion in the coverage of various taxes or the imposition of new taxes. Therefore, the estimation of tax elasticity requires an adjustment to the actual revenue series so as to separate the growth in revenue arising from discretionary changes from that due to automatic changes. This adjustment to tax revenue is made in order to distinguish tax elasticity from tax buoyancy.

There are three major ways of adjusting a revenue series; the constant rate method, the proportional adjustment method and the dummy variable method. The choice of adjustment method employed depends on factors such as the availability of data on tax changes and the type and frequency of such changes. The proportional adjustment method requires calculation of the revenue implications of discretionary measures. Similarly, the constant rate structure method requires disaggregated data on tax rates and tax bases. The dummy variable method on the other hand can not be used when there are frequent discretionary changes. Attention will now focus on a brief discussion of the proportional adjustment method as this methodology is used to adjust revenues in this paper.

\subsection{Proportional Adjustment Method}

The proportional adjustment method adjusts a historical revenue series according to a particular years tax structure on the assumption that this particular tax structure is maintained throughout the period under consideration. Thus, this method basically involves two steps. Firstly, observed revenue data for each year are adjusted for discretionary changes by removing from such data the estimated revenue impact of discretionary changes. This gives an estimate of the automatic growth in revenue between two successive years. Secondly, the series are converted to the first year's basis by adjusting the year to year changes by the ratio of the tax yield on the basis of the first year rates to the actual tax yield (Chelliah and Chand, 1974). Thus, the proportional adjustment method can be used to construct a hypothetical revenue 
series in two ways - a series of accumulated ratios going forward from a reference year or a series of decumulated ratios going backward from a base year. Numerically, the accumulated series can be derived as follows:

$$
T_{1, j}=T_{1, j-1}+\frac{\left(T_{j}-D_{j}-T_{j-1}\right)}{T_{j-1}} \cdot T_{1, j-1}
$$

where $\quad \mathrm{T}_{j}=$ actual revenue in $j^{\text {th }}$ year

$\mathrm{D}_{j}=$ revenue impact of discretionary changes

$\mathrm{T}_{1, j}=$ revenue in $j^{\text {th }}$ year adjusted to structure of $i^{\text {th }}$ year which is base year

In the above case, the reference year for the series constitutes the first year of the series. Similarly, a decumulated adjusted revenue series can also be computed with the last year of the data series constituting the reference year. The general formula used in the construction of such a revenue series can be shown as follows:

$$
T_{n, j}=T_{j} \frac{T_{j+1}}{T_{j, j+1}} \frac{T_{j+2}}{T_{j+1, j+2}} \ldots . . \frac{T_{n}}{T_{n-1, n}}
$$

Graphically, the two series can be illustrated as in chart 1 . The line $A B$ represents the actual unadjusted revenue series with a revenue raising

\section{Chart 1}

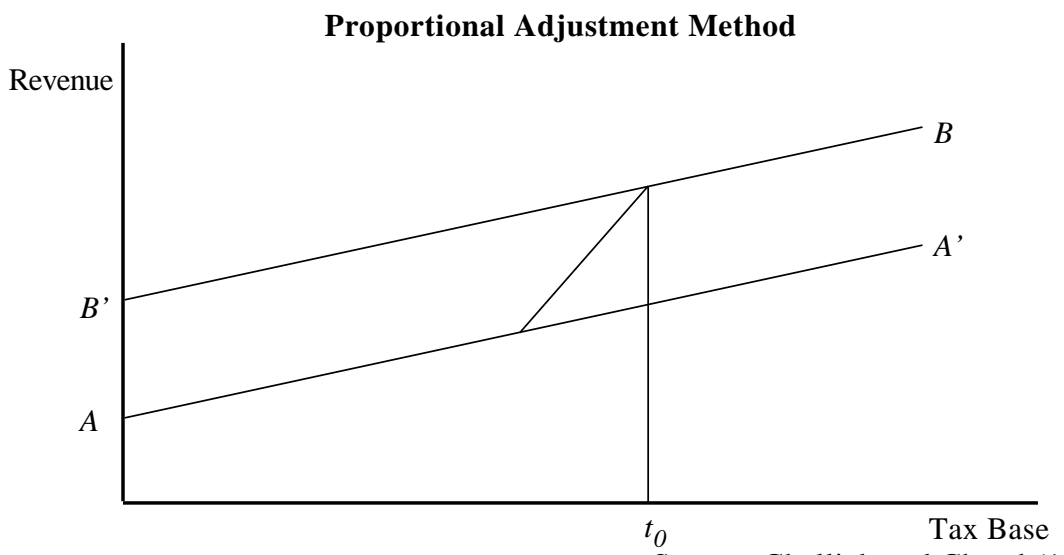

Source: Chelliah and Chand (1974) 
discretionary action taking place at $t=t_{0}$. An adjusted revenue series using the first year tax structure as the base year is shown by line $A A^{\prime}$. Line $A A^{\prime}$ adjusts the observed revenue series by subtracting from all observations the revenue impact of the discretionary change subsequent to the discretionary action at time period $t_{0}$. Similarly, line $B B^{\prime}$ shows an adjusted revenue series with the last year taken as the base year where the revenue impact of the discretionary change has been added to revenue observations occurring prior to the changed tax structure.

An important assumption of the proportional adjustment method is that the revenue impact of the discretionary measure grows in proportion to total revenue. This implies that the proportional adjustment method does not alter the elasticity of the tax system although the tax yield may change due to such actions. In effect, what is derived from the elasticity estimate is an average elasticity of all the tax structures under consideration.

\section{Empirical Analysis}

\subsection{Data}

The paper adopts the Government Finance Statistics (GFS) classification used by the IMF to categorise tax revenue. In line with this classification, tax revenues are classified in accordance with the bases upon which they are levied or the activities due to which the tax liability arises. ${ }^{4}$ Taxes for which several tax bases apply are categorised into the most prominent tax base while fines and interest charges paid for late payment of various taxes are covered under the specific taxes concerned. Since the tax base or the activity concept is defined by law, this classification facilitates economic analysis as taxes constitute an additional cost in supply and demand relationships (GFS, 1986).

The adoption of a tax base categorisation for government revenue necessitated the compilation of a new tax revenue table for Sri Lanka for the period 1950-1996. ${ }^{5}$ Taxes were categorised into the following bases; income and profit, domestic goods and services, international trade, property and a

4/ For example, income taxes are categorised as taxes on income, profit and capital gains as the tax base of income taxes constitute income, profit and capital gains. Import and export taxes are classified as taxes on international trade and transactions as these taxes arise from the importation and exportation of goods.

5/ Prior to 1965 the economic classification of Sri Lanka's revenue was based on the SNA system of the United Nations which categorised tax revenue into current and capital receipts. Before 1955 tax revenue was compartmentalised into direct and indirect taxes wherein the distinction between these two sources was based on the relationship between the government and the taxpayer and not on the shiftability of the tax. 
miscellaneous tax base. Taxes on income and profit constitute those levied on the actual or presumptive income of individuals and profits of businesses. ${ }^{6}$ Taxes on domestic goods and services include all taxes levied on the production, sale and transfer of goods while incorporating taxes on specific services as well as those imposed on the usage of goods. Thus, turnover and excise taxes constitute major categories under this heading while other important such taxes include license taxes and revenue obtained from government monopolies. ${ }^{7}$ Import and export duties comprise the major taxes levied on international trade and transactions. ${ }^{8}$ FEECs revenue is also classified under this category as they represent a transfer to the government of exchange profits resulting from the maintenance of a dual exchange rate. Foreign exchange taxes which were imposed during the pre-1977 period on foreign exchange obtained for travel purposes are also included in this category as they constitute a levy on the payment of invisible imports and exports. Property taxation is defined in accordance to the use, ownership, and the transfer of wealth of movable and immovable property. The main components under property taxation comprise estate duties, wealth taxes, gift taxes and taxes on financial and capital transactions. The tax revenue database compiled in line with the GFS classification for the period 1950-1996 for Sri Lanka is given in Appendix 1.

As legal bases were not available for all tax categories, proxy bases were used for estimating tax revenue elasticities. The proxy bases used for the empirical estimation constituted variables from the national accounts and the balance of payments as the tax categories chosen for the estimation can be associated with bases that cover large parts of economic activity in the country.

\begin{tabular}{|c|c|}
\hline & Proxy Tax Bases \\
\hline$\underline{\text { Tax }} \underline{\text { Re}} \underline{e} \underline{\operatorname{en}} \underline{\mathrm{u}} \underline{\mathrm{e}}$ & Proxy Bas $\underline{e}$ \\
\hline Income Tax & GDP at factor cost current prices \\
\hline Turnover Tax & Private consumption at market prices \\
\hline Excise Tax & Private consumption \\
\hline Import Duties & Imports of goods and services \\
\hline Total Taxes & GDP at current market prices \\
\hline
\end{tabular}

6/ Revenue from taxes on capital gains are also enlisted under this tax base.

7/ The profits of fiscal monopolies constituted an important revenue source during the pre-1977 period as they represented the exercise of monopoly powers of the government for tax purposes.

8/ Taxes on international trade cover levies on goods shipped in or out of the country. 
GDP at factor cost constituted the proxy base for income taxes as the growth of personal and corporate income is reflected in the Gross Domestic Product. Private consumption expenditure is used as a proxy base for turnover taxes as consumption expenditure reflects such taxes which are borne by consumers. ${ }^{9}$ Private consumption is also used for the estimation of excise tax elasticities as excise taxation constitutes a consumption based tax. Import duty elasticities are estimated on a proxy base consisting of imports of goods and services in value terms as import duties are levied on this tax base. Gross Domestic Product at current market prices constitutes the proxy base for total tax revenue.

As the computation of tax elasticities necessitates an adjustment to the observed revenue series, the proportional adjustment method was employed in this paper to adjust the actual revenue series. As mentioned before, the proportional adjustment method adjusts the tax yields in years prior to the reference year to give an indication of the revenue collections that would have been had the reference years tax system been in force throughout the period under study. This method was adopted as the data requirements for this methodology are minimal in that apart from actual revenue collections, what is required is a quantitative impact of discretionary measures. Data on discretionary changes were obtained from budget speeches while actual and estimated revenue data were obtained from the Government Estimates of Revenue and Expenditure and the Central Bank Annual Reports. ${ }^{10}$ Appendix table 2 gives the revenue impact of the discretionary tax changes. ${ }^{11}$

The methodology of constructing an adjusted revenue series can be demonstrated as follows: For a series of actual revenue collections,

$$
T_{1}, T_{2}, \ldots \ldots \ldots \ldots T_{n}
$$

and a series of discretionary measures

$$
D_{1}, D_{2}, \ldots \ldots \ldots \ldots \ldots D_{n}
$$

the adjusted revenue for a particular year can be obtained from the equation:

9/ The forward shifting of taxes by firms to consumers is assumed here.

10/ Although budget presentations are not the only occasion when changes to the revenue structure are made, nevertheless they give a fair indication of important changes made to the tax system.

11/ When a tax measure is announced, it is usually quantified in order to examine the impact on revenue. Appendix table 2 gives ex-ante estimates of tax measures. The paper corrects ex-ante budget estimates by applying ratios of actual to estimated overall yield for each tax. 


$$
A T_{n-1}=T_{n-1}\left(T_{n} / T_{n}-D_{n}\right)
$$

where $\quad A T=$ adjusted tax revenue

$T=$ actual tax revenue

$D=$ revenue effect of discretionary measure

However, for the reference year,

$$
A T_{n}=T_{n}
$$

For each year where a discretionary action takes place, a "discretionary factor", ( $T n / T n-D n)$, is calculated excluding the revenue amount resulting from the legal action for that particular year. Discretionary factors are calculated for all years in which such changes occur. The adjusted revenue series is obtained by multiplying the previous year's revenues by these discretionary factors. The adjusted revenue series gives an approximation of the revenue which could have been obtained had these measures been in force during the previous years. The adjusted tax revenue series is shown in Appendix 3.

A problem encountered with the use of budgetary estimates of discretionary measures is that the actual revenue effect of the discretionary change may differ from the ex-ante budget estimate. One possible method of overcoming this problem is to correct ex-ante budget estimates by applying ratios of actual to estimated overall yield of each tax (IMF, 1993). An assumption underlying this approach is that the percentage error in estimating the revenue effect of a discretionary change would be about the same as that arising from forecasting the overall yield of the same tax (IMF, 1993). Therefore, in order to adjust for the error in forecasting discretionary changes in Sri Lanka, revenue from this measure was adjusted by the ratio of actual to estimated revenue. Appendix table 4 gives the ratios of actual to estimated revenues.

\subsection{Methodology}

The paper utilises a time series regression approach to estimate elasticities for income, turnover, excise and import taxes and total tax revenue. In order to compare the impact of discretionary changes, tax buoyancies are also estimated for the same taxes.

The estimation of tax elasticity through regression analysis is based on the partitioning approach whereby tax elasticity is subdivided into tax to base and base to income elasticity. The functional form of the equation for computing tax to base elasticity is in log linear specification as follows: ${ }^{12}$

12/ The logarithm form is chosen as this gives directly an estimate of elasticity. 


$$
\ln T=a+b \ln X
$$

where $\quad T=$ adjusted tax revenue

$$
X=\operatorname{tax} \text { base }
$$

Similarly, the regression used to estimate base to income elasticity is as follows:

$$
\ln B=a+c \ln Y
$$

where $\quad B=$ tax base

$$
Y=\text { GDP at market prices }
$$

The coefficients $b$ and $c$ in the above two equations give an estimate of the respective elasticities. The product of tax to base and base to income elasticities $(b * c)$ gives an estimate of overall elasticity in this instance. A list of variables used in the elasticity estimation is given below.

\section{Variable List}

$\begin{array}{ll}\text { LAIT } & =\text { Log adjusted income taxes } \\ \text { LATT } & =\text { Log adjusted turnover taxes } \\ \text { LAEXCT } & =\text { Log adjusted excise taxes } \\ \text { LAEXPT } & =\text { Log adjusted export taxes } \\ \text { LAIMPT } & =\text { Log adjusted import taxes } \\ \text { LATTR } & =\text { Log adjusted total tax revenue } \\ \text { LPC } & =\text { Log private consumption } \\ \text { LIMP } & =\text { Log imports (value) } \\ \text { LGDPF } & =\text { Log gross domestic product at factor prices } \\ \text { LGDPM } & =\text { Log gross domestic product at market prices } \\ \text { DP } & =\text { Dummy variable for import duty estimation } \\ \text { IMPD4 } & =\text { Dummy variable for total tax revenue estimation } \\ \text { LITD } & =\text { Dummy variable for income tax estimation } \\ \text { LAITD } & =\text { Dummy variable for income tax estimation } \\ \text { LATTD1 } & =\text { Dummy variable for turnover tax estimation } \\ \text { LATTD2 } & =\text { Dummy variable for turnover tax estimation } \\ \text { LATTD } & =\text { Dummy variable for turnover tax estimation } \\ \text { LAEXCTD1 } & =\text { Dummy variable for excise tax estimation } \\ \text { SLGDPD } & =\text { Dummy variable for total tax revenue } \\ \text { Y } & =\text { Fitted values of LGDPM }\end{array}$

The first step in seeking a methodology for modelling any economic relationship is to ascertain the stationarity of the variables under scrutiny. ${ }^{13}$

13/ Stationarity is an important concept in econometrics since the standard regression model makes assumptions regarding the stationarity of the error term and the variables. A stationary (weakly) time series has a constant mean and variance for all $t$. 
Therefore, a crucial preliminary task in the estimation procedure is to check for the stationarity of variables by testing for their order of integration. ${ }^{14}$ The data were tested for the order of integration through an Augmented Dickey Fuller (ADF) test and checked for the presence of unit roots. ${ }^{15}$

The results of the ADF test are shown in Table 1. The ADF test shows the variables as being $I(1)$ with one unit root although a significant ADF- $t$ statistic is obtained for the first difference of LGDPF only at the 5 per cent level.

Table 1

ADF Test Results

\begin{tabular}{|l|c|c|}
\hline Variable & \multicolumn{1}{|c|}{$I(0)$} & $I(1)$ \\
\hline LAIT & -2.08 & -7.22 \\
LATT & -39.82 & - \\
LAEXCT & -19.97 & - \\
LAIMPT & -0.80 & -6.22 \\
LATTR & -1.04 & -6.09 \\
LPC & -2.29 & -3.94 \\
LIMP & -2.01 & -4.70 \\
LGDPF & -2.56 & -4.15 \\
LGDPM & -2.77 & -4.47 \\
LGDE & -2.38 & -4.04 \\
LIT & -1.93 & -7.27 \\
LTT & -9.22 & - \\
LEXCT & -2.71 & -5.91 \\
LIMPT & -1.64 & -4.62 \\
LTTR & -1.70 & -6.02 \\
\hline
\end{tabular}

Source: Author's Estimates.

Note: $I(0)$ and $I(1)$ refer to the level and the first difference of the variable respectively. The figures shown are $t$ ratios for which a suggested significance value in the ADF test is usually -3.0 or below (Dickey and Fuller, 1979, 1981). A constant and time trend were used in all the unit root estimations.

14/ A variable $x_{t}$ is said to be integrated to the order $\mathrm{d}, x_{t} \sim \mathrm{I}(\mathrm{d})$, if it must be differenced at least d times to reach stationarity.

15/ The presence of unit roots has far reaching implications for economic analysis. Under the unit root hypothesis, random shocks have a permanent effect making the system nonstationary. The ADF test can be used to test for unit roots through the following equation:

$$
\Delta y_{t}=\gamma y_{t-1}+\varepsilon_{t} \text { where } \gamma=\alpha_{1}-1
$$

Testing for unit roots entails testing whether $\alpha_{1}=1$ or $\gamma=0$. If these conditions are fulfilled, the $y_{t}$ series is said to have unit roots. However, the usual caveat regarding the low power of ADF tests in distinguishing between unit roots and near unit roots in small samples applies here. See Dickey and Fuller (1981). 
In performing unit root tests, however, care must be taken if structural breaks are suspected in the data series. The Augmented Dickey Fuller test is biased towards non-rejection of unit roots when structural breaks are incorporated in the data. In such cases, a Perron test can be performed to check for unit roots in the presence of a structural change. ${ }^{16}$

As the ADF test for Sri Lankan data displayed unit roots and the existence of structural breaks in a data series biases the ADF statistic towards non-rejection of unit roots, a Perron test was also carried out for the data series displaying unit roots. ${ }^{17}$ As the Perron test plays a pivotal role in this econometric analysis, it may be useful at this juncture, to engage in a short discussion of this methodology.

The Perron test constitutes a unit root test for a time series affected by a structural change in its mean. The basic premise underlying this methodology is that shocks that affect an economy may be considered as "outlier events" imposing only a transitory as opposed to a permanent effect on the system. ${ }^{18}$ The change is considered as an outlier as it appears very big in relation to other changes observed in the time series. Perron removes the sudden change from the noise function and introduces it in the deterministic part of the series. The noise function is then analysed without the particular "extraordinary event". An assumption underlying this methodology is that shocks are exogenous and are not the result of the data generating process. The statistical methodology applied in this test is an extension of the Dickey Fuller test.

In statistical terms, the Perron methodology can be described as follows. For a time series characterised with a one time change in the structure occurring at time period $T_{B}\left(1<T_{B}<T\right)$, the null hypothesis can be given as:

$$
y_{t}=\mu_{t}+y_{t-1}+d D(T B)_{t}+\left(\mu_{2}-\mu_{1}\right) D U_{t}+e_{t}
$$

16/ Another econometric procedure which can be performed when testing for unit roots in the presence of structural breaks involves splitting the sample and carrying out a Dickey Fuller test on each sub-sample (Enders, 1995). However, in this case, the degrees of freedom for each regression become less. The Perron methodology constitutes a better test as it utilises the full sample.

17/ Perron (1989) challenges Nelson Plosser by showing that most variables do not have unit root processes but are trend stationary processes having structural breaks. Therefore, Perron's test involves testing for unit roots in the presence of structural change either at a known or unknown breakpoint in time. From a series of Monte Carlo experiments, Perron finds that the non-rejection of the unit root hypothesis becomes more probable as the magnitude of the change in the mean increases. See also Perron, 1990, 1992.

18/ Nelson and Plosser (1982) argue that most macroeconomic time series are characterised by stochastic shocks which are nonstationary. The total variability of a time series over time is therefore explained in terms of greater variability on the part of permanent shocks than transitory shocks. 
where $D(T B)=1$ if $t=T_{B}+1$ and 0 otherwise

$D U_{t}=1$ if $t>T_{B}$ and 0 otherwise

The above model allows for a change in the intercept of the trend function as well as a change in the slope of the trend function. The alternative hypothesis in this case can be shown as follows:

$$
y_{t}=\mu_{1}+\beta_{1} t+\left(\mu_{2}-\mu_{1}\right) D U_{t}+\left(\beta_{2}-\beta_{1}\right) \mathrm{DT}_{t}+e_{t}
$$

where $D T_{t}=t$ if $t>T_{B}$ and 0 otherwise

The Dickey Fuller $(D F)$ procedure is used to test for unit roots in the presence of structural break. When errors are uncorrelated, the $D F$ test used is

$$
y_{t}=\alpha y_{t-1}+e_{t}
$$

When the innovation sequence is correlated, the above approach is modified by the addition of extra lags of the first differences of the data as regressors as follows: ${ }^{19}$

$$
y_{t}=\alpha y_{t-1}+\Sigma c \Delta y_{t-j}+e_{t}
$$

where $\Delta y_{t}=y_{t}-y_{t-1}$

In the above equation, $\alpha$, the sum of the autoregressive coefficients, is the OLS estimator and the test for the existence of unit roots comprises $\alpha=1$. The above approach implies an instantaneous change in the trend function. However, there may be times when the economy reacts gradually to a change in the trend function. One way of incorporating such a change is to suppose that the economy responds to a shock to the trend function in the same way as it reacts to any other shock. ${ }^{20}$ Perron then extends the DF framework by adding dummy variables and constructing a model by nesting null and alternative hypotheses as follows:

$$
y_{t}=\mu+\theta D U_{t}+\beta t+\gamma D T_{t}+d D(T B)_{t}+\alpha y_{t-1}+\sum_{i=1}^{k} c_{i} \Delta y_{t-i}+e_{t}
$$

A visual inspection of the data for Sri Lanka for the period 1950-1994 reveals a sudden shift in the mean of the series around 1977. Appendix 5

19/ This approach follows that of Dickey and Fuller (1979) and Said and Dickey (1984).

20/ This methodology is consistent with the "innovational outlier" specification in literature on outlier models. 
gives a time plot of the variables used for the elasticity estimation. Borrowing upon terminology from Perron, this sudden change can be viewed as "extraordinary" against the background of the general historical pattern observed in the series. The reforms initiated with the economic liberalisation in 1977 can be held responsible for this sudden change. Therefore the year 1977 was chosen to represent the break point for the structural break since far reaching economic reforms were undertaken during this year. The Perron test was performed for each variable with unit roots by estimating the following equation:

$$
y_{t}=a_{0}+\mu_{1} D_{L}+\mu_{2} D_{P}+\alpha_{2} t+\alpha_{1} y_{t-1}+\sum_{i=1}^{k} \beta \Delta y_{t-1}
$$

where, $\quad \mathrm{D}_{\mathrm{L}}=$ level dummy and $\mathrm{D}_{\mathrm{L}}=1$ if $t>\tau$ and $\mathrm{D}_{\mathrm{L}}=0$ otherwise

$\mathrm{D}_{\mathrm{P}}=$ pulse dummy and $\mathrm{D}_{\mathrm{P}}=1$ if $t=\tau+1$ and zero otherwise

$\lambda=\tau / \mathrm{T}$ (proportion of observations prior to break)

$\tau=$ breakpoint $=1977$

$t=$ trend

The null hypothesis is that of a unit root process with a one time change in the mean of a unit root process with $\alpha_{1}=1, \alpha_{2}=0$ and $\mu_{2}=0$. The alternative hypothesis predicts a trend stationary model with a permanent one time break with $\alpha_{1}<1$ and $\mu_{1}=0$. The results of the Perron test are given in Table 2 .

Results from the Perron test do not indicate support for the unit root hypothesis. The estimated values of $\alpha_{1}$ for all variables are significantly different from unity at the 5 percent level as shown by the computed t values which are greater than the critical values calculated by Perron. In fact, most variables seem to have a deterministic trend with $\alpha_{2}$ coefficients displaying significant $t$ ratios. The level dummy as measured by $\mu_{1}$ seems to be insignificant for all variables. The pulse dummy as measured by $\mu_{2}$ on the other hand seems to be significant for the variables LAIMPT, LGDPF, LGDE, LIMP, LEXCT, LTTR and LIMPT. Thus, the Perron test seems to reject the null hypothesis of unit roots. The tax variables are stationary and justify the use of level variables in regression analysis.

In the light of the above results, a general to specific modelling strategy in $\log$ levels was adopted which seemed to give satisfactory results. ${ }^{21}$ In order

21/ The general model consisted of an Autoregressive Distributed Lag (ADL) model where the dependent variable is expressed as a function of its own values and current and lagged values of explanatory variables. Considering the small sample nature of the data series, lag lengths of up to three were generally incorporated. The specific model formulation was arrived at by gradually reducing the general model by testing for linear restrictions through Wald tests. See Gilbert (1986), Charemza (1992) and Hendry (1995) for more information on general to specific modelling. 
Table 2

Perron Test Results

\begin{tabular}{|c|c|c|c|c|c|c|c|}
\hline Variable & $\mathrm{T}$ & K & $\lambda$ & $\mu_{1}$ & $\mu_{2}$ & $\alpha_{1}$ & $\alpha_{2}$ \\
\hline LAIT & 42 & 2 & 0.6 & $\begin{array}{c}0.11 \\
(0.65)\end{array}$ & $\begin{array}{l}-0.14 \\
(-0.62)\end{array}$ & $\begin{array}{c}0.84 \\
(8.6)\end{array}$ & $\begin{array}{c}0.01 \\
(1.78)\end{array}$ \\
\hline LAIMPT & 42 & 2 & 0.6 & $\begin{array}{c}0.18 \\
(1.59)\end{array}$ & $\begin{array}{l}-1.02 \\
(-5.6)\end{array}$ & $\begin{array}{c}0.09 \\
(16.14)\end{array}$ & $\begin{array}{l}-0.001 \\
(-0.18)\end{array}$ \\
\hline LATTR & 34 & 10 & 0.5 & $\begin{array}{l}-0.01 \\
(-0.22)\end{array}$ & $\begin{array}{c}0.02 \\
(0.27)\end{array}$ & $\begin{array}{c}0.76 \\
(10.35)\end{array}$ & $\begin{array}{c}0.02 \\
(4.03)\end{array}$ \\
\hline LGDPF & 40 & 5 & 0.6 & $\begin{array}{l}-0.002 \\
(-0.33)\end{array}$ & $\begin{array}{c}0.15 \\
(2.84)\end{array}$ & $\begin{array}{c}0.87 \\
(12.17)\end{array}$ & $\begin{array}{c}0.02 \\
(3.11)\end{array}$ \\
\hline LGDPM & 40 & 5 & 0.6 & $\begin{array}{c}-0.01 \\
(-1.03)\end{array}$ & $\begin{array}{c}0.06 \\
(1.26)\end{array}$ & $\begin{array}{c}0.93 \\
(13.96)\end{array}$ & $\begin{array}{c}0.01 \\
(2.35)\end{array}$ \\
\hline LGDE & 40 & 5 & 0.6 & $\begin{array}{c}0.01 \\
(0.75)\end{array}$ & $\begin{array}{c}0.14 \\
(2.89)\end{array}$ & $\begin{array}{c}0.82 \\
(12.11)\end{array}$ & $\begin{array}{c}0.02 \\
(3.31)\end{array}$ \\
\hline LIMP & 43 & 4 & 0.6 & $\begin{array}{c}0.01 \\
(0.49)\end{array}$ & $\begin{array}{c}0.22 \\
(2.13)\end{array}$ & $\begin{array}{c}0.82 \\
(9.97)\end{array}$ & $\begin{array}{c}0.02 \\
(2.85)\end{array}$ \\
\hline LEXCT & 38 & 2 & 0.7 & $\begin{array}{c}0.08 \\
(1.22)\end{array}$ & $\begin{array}{c}0.22 \\
(2.02)\end{array}$ & $\begin{array}{c}0.58 \\
(5.84)\end{array}$ & $\begin{array}{c}0.07 \\
(3.75)\end{array}$ \\
\hline LTTR & 41 & 3 & 0.6 & $\begin{array}{c}0.06 \\
(0.81)\end{array}$ & $\begin{array}{c}0.45 \\
(4.71)\end{array}$ & $\begin{array}{c}0.94 \\
(19.44)\end{array}$ & $\begin{array}{c}0.01 \\
(1.92)\end{array}$ \\
\hline LIT & 41 & 3 & 0.6 & $\begin{array}{c}0.14 \\
(1.02)\end{array}$ & $\begin{array}{l}-0.1 \\
(-0.15)\end{array}$ & $\begin{array}{c}0.84 \\
(9.29)\end{array}$ & $\begin{array}{c}0.02 \\
(2.21)\end{array}$ \\
\hline LIMPT & 43 & 1 & 0.6 & $\begin{array}{c}0.16 \\
(1.2)\end{array}$ & $\begin{array}{c}0.78 \\
(4.09)\end{array}$ & $\begin{array}{c}0.96 \\
(23.04)\end{array}$ & $\begin{array}{c}0.002 \\
(0.56)\end{array}$ \\
\hline
\end{tabular}

Source: Author's Estimates.

$\mathrm{T}=$ number of observations

$\mathrm{k}=$ lag length

* The figures in parentheses represent $t$ ratios.

** Critical values for the Perron test consisting of a sample of 50 observations are as follows:

$$
\begin{array}{lll}
\lambda=0.5 & \underline{1}-\underline{\%} \underline{0} & \underline{5} \% \\
\lambda=0.6 & -4.11 & -3.45
\end{array}
$$


to compare the responsiveness of tax revenue during the pre-reform period and the post-reform period, elasticities were computed for three sample periods comprising the years 1960-1994, 1960-1977 and 1978-1994. The three sample periods of 1960-1977, 1978-1994 and 1960-1994 were chosen specifically to see the behaviour of the estimated coefficients during vastly different time periods in Sri Lanka's history. While the period 1960-1977 constituted an inward looking state controlled economic regime, the time period 1978-1994 represents an outward oriented market based economic regime. The sample period 1960-1994 incorporates both these economic regimes. The elasticity estimates presented in tables 8 and 9 were obtained from the product of tax to base and base to income elasticities.

\subsubsection{Tax to Base Elasticities}

The tax to base regressions for income taxes shown in Table 3 reflect the significance of GDP as well as income taxes lagged one period in the determination of income tax revenue. The explanatory power of the latter variable seems to be greater partly due to the fact that income taxes are very often subject to lags in collection. Moreover, as tax incentives in the form of tax holidays are a major component of the income tax system, the utilisation of these incentives would erode the tax base thereby lessening the tax to base

Table 3

Tax to Base Income Tax Regression Results*

\begin{tabular}{|l|c|c|c|}
\hline LAIT & $\mathbf{1 9 6 0 - 1 9 9 4}$ & $\mathbf{1 9 6 0 - 1 9 7 7}$ & $\mathbf{1 9 7 8 - 1 9 9 4}$ \\
\hline LAIT $_{\mathrm{t}-1}$ & $\begin{array}{c}0.72 \\
(9.22)\end{array}$ & $\begin{array}{c}0.54 \\
(3.51)\end{array}$ & $\begin{array}{c}0.71 \\
(5.37)\end{array}$ \\
\hline LGDPF & 0.22 & 0.35 & 0.22 \\
& $(3.70)$ & $(2.95)$ & $(2.26)$ \\
\hline LITD (1973=1) & - & 0.33 & - \\
& & $(2.65)$ & -0.59 \\
\hline LAITD (1989=1) & -0.61 & - & $(-3.50)$ \\
& $(-3.99)$ & & \\
Test Statistics & & & -0.99 \\
$\mathrm{R}^{2}$ & 0.99 & 0.99 & 0.1635 \\
Durbin - h Statistic & -1.28 & -1.30 & 0.3744 \\
SEE & 0.1513 & 0.1172 & 0.2060 \\
RSS & 0.7328 & & \\
\hline
\end{tabular}

Source : Author's Estimates

* Figures below coefficients in parenthesis represent $t$ ratios. 
relationship between income taxes and GDP. The negative LAITD variable used in the income tax elasticity estimations reflects the sharp decline in income tax revenue collections on account of civil disturbances and slow economic growth in 1989. All test statistics for the three sub-periods seem to be significant. The Durbin-h statistic which tests for autocorrrelation when lagged variables are present does not reject the null hypothesis of no autocorrelation for these regressions.

The tax to base regressions estimated for turnover taxes (Table 4) show the significance of the tax base private consumption in explaining turnover tax revenue. LPC is highly significant during all three sub-periods with the period 1978-1994 bearing a coefficient of 0.84 having the highest explanatory power in explaining turnover tax revenue. The LATTD1 dummy used in the turnover tax elasticity estimations for the period 1960-1977 reflects the introduction of the FEEC scheme in the form of a dual exchange rate system in May, 1968. As imports constitute a major component of private consumption,

Table 4

Tax to Base Turnover Tax Regression Results*

\begin{tabular}{|c|c|c|c|}
\hline LATT & 1960-1994 & 1960-1977 & 1978-1994 \\
\hline Constant & $\begin{array}{c}0.10 \\
(0.62)\end{array}$ & $\begin{array}{c}1.47 \\
(4.99)\end{array}$ & $\begin{array}{c}0.46 \\
(-2.09)\end{array}$ \\
\hline $\operatorname{LATT}_{\mathrm{t}-1}$ & $\begin{array}{c}0.10 \\
(6.4)\end{array}$ & $\begin{array}{c}0.12 \\
(13.14)\end{array}$ & - \\
\hline LPC & $\begin{array}{r}0.71 \\
(33.2)\end{array}$ & $\begin{array}{c}0.55 \\
(15.85)\end{array}$ & $\begin{array}{c}0.84 \\
(45.28)\end{array}$ \\
\hline LATTD1 $(1969=1)$ & - & $\begin{array}{c}0.16 \\
(2.68)\end{array}$ & - \\
\hline LATTD2 $(1970=1)$ & - & $\begin{array}{c}-0.30 \\
(-5.08) \\
\end{array}$ & - \\
\hline LATTD $(1981=1)$ & - & - & $\begin{array}{c}0.23 \\
(3.83) \\
\end{array}$ \\
\hline $\begin{array}{l}\text { Test Statistics } \\
\mathrm{R}^{2} \\
\text { Durbin - d Statistic } \\
\text { Durbin - h Statistic } \\
\text { SEE } \\
\text { RSS }\end{array}$ & $\begin{array}{l}0.99 \\
- \\
0.14 \\
0.09911 \\
0.2652\end{array}$ & $\begin{array}{l}0.99 \\
- \\
-0.84 \\
0.0554 \\
0.0276\end{array}$ & $\begin{array}{l}0.99 \\
1.98 \\
- \\
0.0560 \\
0.0439\end{array}$ \\
\hline
\end{tabular}

Source : Author's Estimates

* Figures below coefficients in parenthesis represent $t$ ratios. 
the introduction of this scheme would have had a major impact on private consumption and therefore on turnover tax revenue collections. The positive LATTD dummy variable in the turnover tax estimations for the 1978-1994 period reflects the imposition of turnover taxes on imports in 1981 which shows a revenue augmentation impact for turnover taxes as a result of a base broadening effect. Test statistics for the turnover tax regression are also significant.

The short run elasticities for excise taxes generally point to low estimates (Table 5).

Table 5

Tax to Base Excise Tax Regression Results*

\begin{tabular}{|l|c|c|c|}
\hline LAEXCT & $\mathbf{1 9 6 0 - 1 9 9 4}$ & $\mathbf{1 9 6 0 - 1 9 7 7}$ & $\mathbf{1 9 7 8 - 1 9 9 4}$ \\
\hline Constant & 1.07 & -0.69 & 6.70 \\
& $(3.58)$ & $(-1.24)$ & $(12.99)$ \\
\hline LAEXCT $_{\mathrm{t}-1}$ & 0.70 & - & - \\
\hline LPC & $(7.11)$ & & 1.48 \\
& 1.34 & 0.90 & $(2.59)$ \\
\hline LPC $_{\mathrm{t}-1}$ & $(3.18)$ & $(14.77)$ & -1.29 \\
& -1.22 & - & $(-2.33)$ \\
\hline LAEXCTD1 (1988=1) & $(-3.03)$ & & -0.30 \\
& - & - & $(-2.75)$ \\
\hline Test Statistics & & & 0.71 \\
$\mathrm{R}^{2}$ & & & 1.60 \\
Durbin - d Statistic & - & 0.93 & - \\
Durbin - h Statistic & -0.40 & - & 0.1060 \\
SEE & 0.1450 & 0.1506 & 0.1461 \\
RSS & 0.6309 & 0.3854 & \\
\hline
\end{tabular}

Source : Author's Estimates

* Figures below coefficients in parenthesis represent $t$ ratios.

During the period 1960-1994 the short run elasticity estimates amount to 0.12 while during the post-liberalisation period this estimate improves to 0.19 . The specific nature of the excise taxation can largely explain the low elasticities found in this revenue source. The short run elasticity estimate for excise tax revenue during the 1960-1977 period is relatively high at 0.90 due to the improved effort put into tax administration during this period. All test statistics are significant for all estimations. 
Import tax revenue (Table 6) reflect very low tax to base elasticities during the 1960-1994 period and 1960-1977 sub-period. An important factor that seems to be affecting the results of the estimation for import taxes seems to be the imposition of import restrictions in the form of quotas during the 1970-1977 period. As the period 1970-1977 was characterised by quantitative restrictions, this would have exerted a downward bias on the estimates. The insignificant $t$ statistic observed for the tax base variable LIMP for the elasticity estimation of 1960-1977 provides further evidence of the importance of import substitution policies during this period. On the other hand, import duties, lagged one period, turns out to be an insignificant explanatory variable for the elasticity estimation during the post-liberalisation period. This can be due to the fact that import duties are usually collected promptly, without a lag, as goods can not be released before payment of duty.

Table 6

Tax to Base Import Tax Regression Results*

\begin{tabular}{|l|c|c|c|}
\hline LAIMPT & $\mathbf{1 9 6 0 - 1 9 9 4}$ & $\mathbf{1 9 6 0 - 1 9 7 7}$ & $\mathbf{1 9 7 8 - 1 9 9 4}$ \\
\hline LAIMPT $_{\mathrm{t}-1}$ & $\begin{array}{c}0.94 \\
(45.31)\end{array}$ & $\begin{array}{c}0.93 \\
(21.79)\end{array}$ & $\begin{array}{c}0.23 \\
(1.42)\end{array}$ \\
\hline LIMP & 0.06 & 0.07 & 0.63 \\
& $(3.29)$ & $(1.45)$ & $(4.70)$ \\
\hline DP (1978=1) & -0.88 & - & - \\
& $(5.08)$ & & \\
\hline Test Statistics & & & 0.99 \\
$\mathrm{R}^{2}$ & 0.99 & 0.99 & 1.83 \\
Durbin - h Statistic & 1.17 & 1.54 & 0.1796 \\
SEE & 0.1709 & 0.1931 & 0.4839 \\
RSS & 0.9347 & 0.5966 & \\
\hline
\end{tabular}

Source : Author's Estimates

* Figures below coefficients in parenthesis represent $t$ ratios.

However, the generally low import elasticity estimates obtained during the post-liberalisation period can be attributed to the plethora of duty waivers and exemptions available during this period. The DP dummy used in the import duty elasticity calculations in 1978 reflects the adoption of liberalised policies in November, 1977.

Tax to base elasticities for total taxes (Table 7) also reflect very low elasticity estimates. An important factor that seems to be affecting the results of the estimation for total tax revenue seems to be the imposition of import 
restrictions in the form of quotas during the 1970-1977 period. Moreover, the low elasticities observed in excise taxes would also have contributed to the low estimate for total taxes. A noteworthy feature is the high $\mathrm{R}^{2}$ observed for all the regressions. This is as expected as many aggregate economic models assume that tax revenues are functionally related to GDP (Mansfield, 1972). This bears out such an assumption on purely statistical grounds as opposed to causative grounds.

Table 7

Tax to Base Total Tax Regression Results*

\begin{tabular}{|l|c|c|c|}
\hline LATTR & $\mathbf{1 9 6 0 - 1 9 9 4}$ & $\mathbf{1 9 6 0 - 1 9 7 7}$ & $\mathbf{1 9 7 8 - 1 9 9 4}$ \\
\hline Constant & 0.95 & - & - \\
& $(2.69)$ & & 0.90 \\
LATTR $_{\mathrm{t}-1}$ & 0.76 & 0.85 & $(17.42)$ \\
\hline LGDPM & $(10.81)$ & $(22.45)$ & 0.77 \\
& 0.14 & 0.15 & $(3.09)$ \\
\hline LGDPM $_{\mathrm{t}-1}$ & $(4.07)$ & $(3.89)$ & -0.69 \\
& - & - & $(-2.96)$ \\
\hline SLGDPD & & & 0.23 \\
& 0.02 & - & $(4.0)$ \\
\hline Test Statistics & $(3.40)$ & & 0.99 \\
$\mathrm{R}^{2}$ & & & -0.54 \\
Durbin-h Statistic & 0.99 & 0.99 & 0.0515 \\
SEE & 0.52 & -0.98 & 0.0345 \\
RSS & 0.0682 & 0.0722 & \\
\hline
\end{tabular}

Source : Author's Estimates

* Figures below coefficients in parenthesis represent $t$ ratios.

\subsubsection{Base to Income Elasticities}

In estimating base to income elasticities, a problem encountered in the estimation procedure was the existence of simultaneity bias in the equations. ${ }^{22}$ The variables LPC, LGDPF, LIMP and LGDPM were thought to be endogenous

22/ The bias in the base to income elasticities arises from the simultaneous determination of the dependent and the exogenous variables. For example, in a simple consumption function of the form $C_{t}=\alpha+\beta Y_{t}+\mu_{t}$, the variables $Y_{t}$ and $C_{t}$ are simultaneously dependent on each other as $Y_{t}=C_{t}+I_{t}+G_{t}+(X-M)$. OLS is not consistent in this case as the endogenous variables in the r.h.s. are correlated with the error term. 
and hence a Two Stage Least Squares (2SLS) approach was adopted in estimating these equations. The structural form of the base to income elasticity equations for private consumption, to cite one example, was as follows:

$$
L P C=\alpha_{1}+\beta_{1} L G D P M+u
$$

As LGDPM constituted the endogenous variable in all the base to income equations to be purged of its stochastic content, the first stage of the 2SLS procedure involved the estimation of the following regression to obtain fitted values of LGDPM:

$$
\begin{aligned}
L G D P M= & 0.23+0.19 L G+0.82 L^{L} G D P M_{t-1} \\
& (1.6) \quad(3.1)
\end{aligned}
$$

$\mathrm{R}^{2}=0.99, \quad$ Durbin h statistic $=0.53 \quad \mathrm{RSS}=0.14 \quad \mathrm{SEE}=0.05$

Government expenditure (LG) and lagged LGDPM were two exogenous variables that were used to estimate the fitted values in the first stage of the 2SLS procedure. In the second stage, the fitted values, (Y), were used in the structural equations to estimate base to income elasticities. The fitted values satisfy two necessary conditions for a valid instrument; firstly, it has no correlation with the error term in the structural equation and secondly, it is highly correlated with the endogenous variable.

The base to income elasticities were estimated as follows:

$$
\begin{aligned}
& L G D P F=-0.10+1.006 Y-0.12 D \\
& (-2.09) \quad(195) \quad(-3.15) \\
& \mathrm{R} 2=0.99 \quad \mathrm{DW}=1.75 \quad \mathrm{RSS}=0.09 \quad \mathrm{SEE}=0.05 \\
& L P C=-0.38+1.38 Y-0.38 Y_{t-1}-0.19 D \\
& \begin{array}{llll}
(-5.2) \quad(9.2) \quad(-2.4) \quad(3.4)
\end{array} \\
& \mathrm{R} 2=0.99 \quad \text { Durbin }-\mathrm{h}=0.90 \quad \mathrm{RSS}=0.09 \quad \mathrm{SEE}=0.05 \\
& \text { LIMP }=-0.72+0.71 \text { LIMP }_{t-1}-1.04 Y_{t-1}+1.36 Y+0.31 D
\end{aligned}
$$

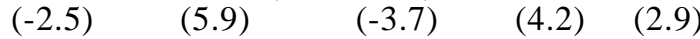

$$
\begin{aligned}
& \mathrm{R} 2=0.99 \text { Durbin }-\mathrm{h}=0.92 \quad \mathrm{RSS}=0.31 \quad \mathrm{SEE}=0.10
\end{aligned}
$$

Base to income elasticities were estimated for the periods 1960-1994, 1959-1977 and 1978-1994. The elasticity estimates in all cases, except import duties, turned out to be equal to one. ${ }^{23}$ In the case of base to income elasticities of import duties, the estimated coefficient turned out to be 1.1081 .

23/ As the elasticity estimates all turned out to be equal to unity, the regressions for the period 1960-1994 only are reported above. 


\section{Results}

Long run and short run elasticities for the above mentioned taxes were computed from the regressions, the results of which are given in Tables 8 and $9 .{ }^{24}$ As mentioned before, the overall elasticity of individual taxes was estimated by the product of the tax to base and base to income elasticities.

Table 8

Long Run Tax Elasticities*

\begin{tabular}{|l|c|c|c|}
\hline Tax & $\mathbf{1 9 6 0 - 1 9 9 4}$ & $\mathbf{1 9 6 0 - 1 9 7 7}$ & $\mathbf{1 9 7 8 - 1 9 9 4}$ \\
\hline Income taxes & $\begin{array}{c}0.78 \\
(0.012)\end{array}$ & $\begin{array}{c}0.76 \\
(0.007)\end{array}$ & $\begin{array}{c}0.76 \\
(0.023)\end{array}$ \\
\hline Turnover taxes & $\begin{array}{c}0.80 \\
(0.016)\end{array}$ & $\begin{array}{c}0.63 \\
(0.037)\end{array}$ & $\begin{array}{c}0.84 \\
(0.019)\end{array}$ \\
\hline Excise taxes & $\begin{array}{c}0.43 \\
(0.073)\end{array}$ & $\begin{array}{c}0.90 \\
(0.062)\end{array}$ & $\begin{array}{c}0.20 \\
(0.040)\end{array}$ \\
\hline Import taxes & $\begin{array}{c}1.12 \\
(0.067)\end{array}$ & $\begin{array}{c}1.13 \\
(0.099)\end{array}$ & $\begin{array}{c}0.91 \\
(0.006)\end{array}$ \\
\hline Total taxes & $\begin{array}{c}0.58 \\
(0.045)\end{array}$ & $\begin{array}{c}1.01 \\
(0.014)\end{array}$ & $\begin{array}{c}0.85 \\
(0.032)\end{array}$ \\
\hline
\end{tabular}

Source: Author's Estimates

* Standard errors are reported in parenthesis

Table 9

Short Run Tax Elasticities*

\begin{tabular}{|l|c|c|c|}
\hline Tax & $\mathbf{1 9 6 0 - 1 9 9 4}$ & $\mathbf{1 9 6 0 - 1 9 7 7}$ & $\mathbf{1 9 7 8 - 1 9 9 4}$ \\
\hline Income taxes & $\begin{array}{c}0.22 \\
(0.15)\end{array}$ & $\begin{array}{c}0.15 \\
(0.12)\end{array}$ & $\begin{array}{c}0.22 \\
(0.16)\end{array}$ \\
\hline Turnover taxes & $\begin{array}{c}0.71 \\
(0.10)\end{array}$ & $\begin{array}{c}0.55 \\
(0.05)\end{array}$ & $\begin{array}{c}0.84 \\
(0.06)\end{array}$ \\
\hline Excise taxes & 0.12 & 0.90 & 0.19 \\
& $(0.14)$ & $(0.38)$ & $(0.11)$ \\
\hline Import taxes & 0.06 & 0.07 & 0.63 \\
& $(0.17)$ & $(0.19)$ & $(0.18)$ \\
\hline Total taxes & 0.14 & $\begin{array}{c}0.15 \\
(0.07)\end{array}$ & $\begin{array}{c}0.08 \\
\end{array}$ \\
\hline
\end{tabular}

Source: Author's Estimates

* Standard errors are reported in parenthesis 
In order to see the effect of discretionary changes on tax revenues, buoyancies were also estimated for the above mentioned taxes. ${ }^{25}$ The buoyancy estimates along with standard errors are given in Table 10 .

Table 10

Tax Buoyancies*

\begin{tabular}{|l|c|c|c|}
\hline Tax & $\mathbf{1 9 6 0 - 1 9 9 4}$ & $\mathbf{1 9 6 0 - 1 9 7 7}$ & $\mathbf{1 9 7 8 - 1 9 9 4}$ \\
\hline Income taxes & $\begin{array}{c}0.94 \\
(0.02)\end{array}$ & $\begin{array}{c}0.92 \\
(0.07)\end{array}$ & $\begin{array}{c}0.97 \\
(0.05)\end{array}$ \\
\hline Turnover taxes & $\begin{array}{c}1.35 \\
(0.06)\end{array}$ & $\begin{array}{c}1.62 \\
(0.37)\end{array}$ & $\begin{array}{c}1.18 \\
(0.18)\end{array}$ \\
\hline Excise taxes & 0.79 & 0.63 & 0.76 \\
& $(0.13)$ & $(0.56)$ & $(0.66)$ \\
\hline Import taxes & 1.42 & 0.88 & 0.92 \\
& $(0.21)$ & $(0.06)$ & $(0.02)$ \\
\hline Total taxes & 1.00 & 0.98 & 0.95 \\
& $(0.15)$ & $(0.23)$ & $(0.11)$ \\
\hline
\end{tabular}

Source: Author's Estimates

* Standard errors are reported in parenthesis

The results from the elasticity estimation point to several noteworthy features of the Sri Lankan tax system. Firstly, low elasticities can be observed for all taxes during the period under study. The growth in tax revenues has not kept pace with that of tax bases. Income taxes show an elasticity estimate of 0.78 for the whole period under study. The elasticity estimates for the pre-reform and the post-reform periods at 0.76 show that income tax revenues have not increased in line with GDP growth. Excise taxes exhibit a very low elasticity of 0.20 during the post-1977 period reflecting the combined effect of the specific nature of excise taxation and the high growth in private consumption during this period. In addition, factors such as the illicit production of liquor impose a negative effect on excise tax elasticity as this is not captured in the national accounts data. In contrast, the relatively high

24/ The long run elasticity of $y$ with respect to $x$ of an ADL equation $y_{t}=\beta_{1} x_{t}+b_{2} x_{t-1}+\gamma y_{t-1}$ specified in logs can be derived as $\eta=\frac{\beta_{1}+\beta_{2}}{1-\gamma}$

25/ A similar procedure to the elasticity estimation was adopted for the buoyancy estimation except that the dependent variable in the latter case constituted actual revenue as opposed to adjusted revenue. 
elasticity of 0.90 observed for excise taxes during the 1970-1977 period points to strengthened tax administration during this period. Turnover taxes, in comparison to other tax sources, have been more responsive to increases in its tax base displaying long run coefficients of around 0.80 during the period under study. There seems to be no significant difference between the turnover tax elasticity estimates for the pre-liberalisation and the post-liberalisation periods. Import taxes as noted before record an elasticity estimate of unity prior to 1977 while the post-1977 period witnesses an elasticity estimate of 0.80. The lower import tax elasticities obtained for the post-liberalisation period reflect the provision of duty waivers and exemptions prevalent during this period resulting in a lowering of the elasticity estimate. The elasticity for total tax revenue is 0.80 from 1978 onwards reflecting an inelastic tax structure even with the implementation of tax reforms.

Another distinct feature that can be observed from the above estimation is the generally lower elasticity estimates obtained for the short run. This is in line with a priori expectations when factors such as lags in collection would always make for delays in payment. Income taxes display very low short run elasticities which may be due to collection lags arising from low tax compliance and weak tax administration. Turnover taxes record relatively higher short run tax elasticities for all periods under study as these tax payments are made quarterly. In the case of excise taxes, the short run and the long run elasticities at 0.90 during the $1960-1977$ period are quite high mainly due to strengthened tax administration during this period. The lowest short run elasticities are found in total tax revenue which is not a surprising result as collection lags in all sources of tax revenue will be incorporated in this variable.

As regards the finally preferred estimates, from an econometric point of view, estimates obtained from the longest sample period may be thought of as the preferred estimates as this sample period incorporates the largest number of observations. In such circumstances, the sample period 1960-1994 can be cited as the period bearing the desired estimates. However, in the case of Sri Lanka, this sample period incorporates the inward oriented, state interventionist and import and exchange controlled time period which would have had some impact on the elasticity estimates derived for this period. Moreover, the choice of preferred estimate must also be based on the purpose for which the elasticity estimates are being used. As revenue forecasting would be a priority area for which these elasticity coefficients can be used, utilising estimates from a sample period similar to the forecasting period would be desirable. As such, the elasticity coefficients arising from the sample period 1978-1994 can be chosen as the finally preferred estimates. 


\section{Conclusion}

The time series analysis of tax elasticity reveals a very inelastic tax structure for the period 1960 - 1994. Taxes are not greatly responsive to changes in income with most elasticity coefficients registering below unity. The low elasticity observed in the Sri Lankan tax system is explained through factors such as exemptions, tax incentives, duty waivers, low compliance and vibrant sectors of the economy which are not subject to taxation. Thus, the automatic responsiveness of taxes to income is seen to be low. The pre-reform and the post-reform periods did not reveal a significant difference in elasiticities for most taxes. In fact, the higher coefficients obtained through the buoyancy analysis point to the role of discretionary measures in maintaining a steady source of tax revenue throughout the period under study. Therefore, the tax reforms implemented during the post-1977 period seem not to have brought about an increase in the elasticity of the tax system. 


\section{Bibliography}

Caminada, and K. Goudswaard, (1996) "Progression and Revenue Effects of Income Tax Reform” International Tax and Public Finance, Vol.3: pp. 57-66

Central Bank of Sri Lanka. Annual Reports and the Review of the Economy. Colombo.1950-1996.

Charemza, W, and D. Deadman, (1992). New Directions in Econometric Practice:General to Specific Modelling, Cointegration and Vector Autoregression. (Cambridge: Edward Elgar).

Chelliah, J., and K. Chand, (1974). “A Note on Techniques of Adjusting Tax Revenue Series for Discretionary Changes" Working Paper FAD/74/1, (Washington : IMF).

Choudhry, N. (1979). Measuring the Elasticity of Tax Revenue: A Divisia Index Approach” IMF Staff Papers, Vol.26, pp. 87-122.

Creedy, J., and N. Gemmell, (1982). "The Built-in Flexibility of Progressive Income Taxes: A Simple Model” Public Finance, Vol.37, No.3, pp. 361371.

Dickey, D. A., and Fuller, W.A. (1979). "Distribution of the Estimators for Autoregressive Time Series with a Unit Root" Journal of the American Statistical Association, Vol.74, pp. 427-431.

(1981) "The Likelihood Ratio Statistics for Autoregressive Time Series with a Unit Root" Econometrica, Vol.49, pp. 1057-1072.

Dorrington, J.C. (1974). "A Structural Approach to Estimating the Built-in Flexibility of UnitedKingdom Taxes on Personal Income" Economic Journal, Vol.84, pp. 576-594.

Enders, W. (1995). Applied Econometric Time Series (New York : John Wiley).

Fries, A., Hutton, J.P., and Lambert, P.J. (1982). "The Elasticity of the U.S. Individual Income Tax: Its Calculations, Determinants and Behaviour" Review of Economics and Statistics, Vol.64, pp. 147-151.

Gilbert, C. (1986). "Professor Hendry's Methodology" Oxford Bulletin of Economics and Statistics, Vol.48, pp. 283-307.

Hendry, D.F. (1995). Dynamic Econometrics (Oxford : Oxford University Press).

Hutton, J.P., and Lambert, P.J. (1980). "Evaluating Income Tax Revenue Elasticities" Economic Journal, Vol.90, pp.901-906.

(1982a). "Modelling the Effects of Income Growth and Discretionary Changes on the Sensitivity of U.K. Income Tax Revenue" Economic Journal, Vol.92, pp.145-155. 
(1982b). "Simulating the Revenue Elasticity of an Individual Income Tax" Economic Letters, Vol.9, pp.175-179.

International Monetary Fund (1993). "Workshop on Budget Forecasting", INST/93-I/I-B-7W, Washington : IMF Institute.

Washington.

Jayasundera, P.B. (1989). “A Study of the Elasticity of the Tax System in Sri Lanka 1978/1988” Staff Studies, Vol. 17 No. 1 \& 2, pp. 37-79.

Johnson, P., and P.J. Lambert, (1989). "Measuring the Responsiveness of Income Tax Revenue to Income Growth: A Review and some U.K. Values" Fiscal Studies, Vol.10, No.1, pp.1-18.

Lambert, Peter J. (1993). The Distribution and Redistribution of Income: A Mathematical Analysis. (Manchester: Manchester University Press).

Mansfield, C.Y. (1972). "Elasticity and Buoyancy of a Tax System: A Method Applied to Paraguay" IMF Staff Papers, Vol.19, pp.425-443.

Ministry of Finance and Planning. Budget Speeches, Colombo,1950-1994.

Estimates of Revenue and Expenditure (various years). Colombo.

Nelson, C.R., and Plosser, C.I., (1982). "Trends and Random Walks in Macroeconomic Time Series" Journal of Monetary Economics, Vol.10, pp.139-162.

Perron, P. (1989). "The Great Crash, the Oil Price Shock and the Unit Root Hypothesis" Econometrica, Vol.57, pp.1361-1401.

(1990). "Testing for a Unit Root in a Time Series with a Changing Mean” Journal of Business and Economic Statistics, Vol.8, No.2, pp.153162.

(1992). "Non-stationarity and Level Shifts with an Application to Purchasing Power Parity" Journal of Business and Economic Statistics, July 1992, Vol.10, No.3, pp.301-320.

Prest, A.R.(1962). "The Sensitivity of the Yield of Personal Income Tax in the United Kingdom" Economic Journal, Vol.72, pp.576-596.

Ram, R. (1991). "Elasticity of Individual Income Tax in the United States" National Tax Journal, Vol.44, pp.93-99.

Tanzi, V. (1969). "Measuring the Sensitivity of the Federal Income Tax from Cross Section Data: A New Approach" Review of Economics and Statistics, Vol.84, pp.576-594.

(1976). "The Sensitivity of the Yield of the U.S. Individual Income Tax and the Tax Reforms of the Past Decade" IMF Staff Papers, Vol.23, pp.441-452.

World Bank, (1991), Lessons of Tax Reform. (Washington: World Bank). 
Tax Revenue

Appendix 1

(Rs. Million)

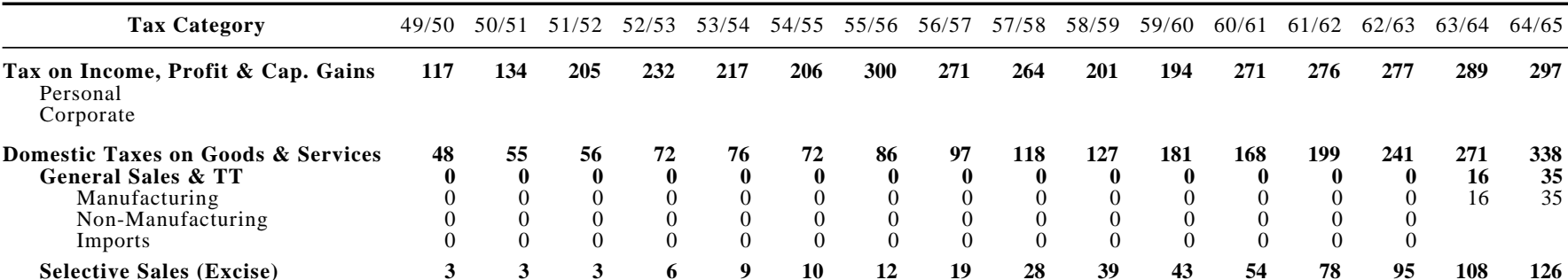

(Excise)

Liquor

Other

Defence Levy

Licence Tax

Heavy Oil Motor Vehicle Tax

Surplus of Govt. Monopolie

Taxes on Specific Services

Betting/Lottery Tax

Taxes on International Trade Import Duties

Export Duties

Foreign Exchan

FEECs Revenue

Taxes on Property

Estate Duties

Wealth Tax / Gift Tax

Taxes on Financial \& Cap. Trans.

Treasury Bill Tax

Property Transfer Tax

Bank Debits Tax

\begin{tabular}{|c|c|c|c|c|c|c|c|c|c|c|c|c|c|c|c|}
\hline 0 & 0 & 0 & 0 & 0 & 0 & 0 & 0 & 0 & 0 & 0 & 0 & 0 & 0 & 0 & 0 \\
\hline 13 & 15 & 16 & 21 & 22 & 18 & 19 & 20 & 32 & 26 & 58 & 44 & 38 & 35 & 41 & 39 \\
\hline 0 & 1 & 1 & 2 & 2 & 3 & 3 & 4 & 3 & 3 & 1 & 2 & 9 & 11 & 14 & 42 \\
\hline 29 & 33 & 33 & 39 & 39 & 34 & 46 & 50 & 52 & 55 & 76 & 65 & 72 & 98 & 88 & 90 \\
\hline 3 & 4 & 4 & 5 & 5 & 8 & 6 & 4 & 3 & 3 & 3 & 3 & 2 & 2 & 5 & 6 \\
\hline 3 & 4 & 4 & 5 & 5 & 8 & 6 & 4 & 3 & 3 & 3 & 3 & 2 & 2 & 5 & 6 \\
\hline 357 & 529 & 489 & 446 & 505 & 630 & 610 & 629 & 618 & 698 & 708 & 733 & 758 & 677 & 765 & 756 \\
\hline 188 & 245 & 260 & 251 & 244 & 258 & 286 & 303 & 292 & 367 & 406 & 435 & 465 & 397 & 481 & 436 \\
\hline 169 & 284 & 229 & 195 & 261 & 372 & 324 & 326 & 326 & 331 & 302 & 298 & 293 & 280 & 280 & 315 \\
\hline 0 & 0 & 0 & 0 & 0 & 0 & 0 & 0 & 0 & 0 & 0 & 0 & 0 & 0 & 4 & 5 \\
\hline 0 & 0 & 0 & 0 & 0 & 0 & 0 & 0 & 0 & 0 & 0 & 0 & 0 & 0 & 0 & 0 \\
\hline 6 & 4 & 6 & 5 & 7 & 7 & 6 & 3 & 16 & 16 & 19 & 31 & 30 & 32 & 32 & 37 \\
\hline 6 & 4 & 6 & 5 & 7 & 7 & 6 & 3 & 5 & 7 & 8 & 10 & 9 & 8 & 8 & 7 \\
\hline 0 & 0 & 0 & 0 & 0 & 0 & 0 & 0 & 0 & 0 & 1 & 12 & 12 & 12 & 13 & 19 \\
\hline 0 & 0 & 0 & 0 & 0 & 0 & 0 & 0 & 11 & 9 & 10 & 9 & 9 & 12 & 11 & 11 \\
\hline 0 & 0 & 0 & 0 & 0 & 0 & 0 & 0 & 0 & 0 & 0 & 0 & 0 & 0 & 0 & 0 \\
\hline 0 & 0 & 0 & 0 & 0 & 0 & 0 & 0 & 0 & 0 & 0 & 0 & 0 & 0 & 0 & 0 \\
\hline 0 & 0 & 0 & 0 & 0 & 0 & 0 & 0 & 11 & 9 & 10 & 9 & 9 & 12 & 11 & 11 \\
\hline
\end{tabular}

Other Taxes

\begin{tabular}{llllllllllllllll}
$\mathbf{9}$ & $\mathbf{1 3}$ & $\mathbf{1 2}$ & $\mathbf{1 3}$ & $\mathbf{1 3}$ & $\mathbf{1 1}$ & $\mathbf{1 2}$ & $\mathbf{1 3}$ & $\mathbf{8}$ & $\mathbf{1 2}$ & $\mathbf{1 3}$ & $\mathbf{1 2}$ & $\mathbf{1 3}$ & $\mathbf{1 4}$ & $\mathbf{1 4}$ & $\mathbf{1 5}$ \\
9 & 13 & 12 & 13 & 13 & 11 & 12 & 13 & 8 & 12 & 13 & 12 & 13 & 14 & 14 & 15 \\
\hline
\end{tabular}

Tax Revenue

$\mathbf{5 3 7} \mathbf{7 3 6}$

$769 \quad 769$

$\begin{array}{llllllllllll}819 & 926 & 1,013 & 1,013 & 1,025 & 1,054 & 1,115 & 1,215 & 1,277 & 1,241 & 1,371 & 1,443\end{array}$


Tax Revenue

Appendix 1 (Contd.)

\begin{tabular}{|c|c|c|c|c|c|c|c|c|c|c|c|c|c|c|c|c|}
\hline Tax Category & $65 / 66$ & $66 / 67$ & $67 / 68$ & $68 / 69$ & $69 / 70$ & $70 / 71$ & $71 / 72$ & 73 & 74 & 75 & 76 & 77 & 78 & 79 & 80 & 81 \\
\hline $\begin{array}{l}\text { Tax on Income, Profit \& Cap. Gains } \\
\text { Personal } \\
\text { Corporate }\end{array}$ & 281 & 312 & 321 & 349 & 445 & 447 & 453 & $\begin{array}{l}704 \\
246 \\
458\end{array}$ & $\begin{array}{l}\mathbf{6 0 6} \\
190 \\
416\end{array}$ & $\begin{array}{l}770 \\
258 \\
512\end{array}$ & $\begin{array}{l}935 \\
253 \\
682\end{array}$ & $\begin{array}{l}937 \\
287 \\
650\end{array}$ & $\begin{array}{r}\mathbf{1 , 1 0 2} \\
384 \\
718\end{array}$ & $\begin{array}{r}\mathbf{1 , 3 5 7} \\
386 \\
971\end{array}$ & $\begin{array}{r}2, \mathbf{0 8 6} \\
378 \\
1,708\end{array}$ & $\begin{array}{r}\mathbf{2 , 0 2 9} \\
570 \\
1,459\end{array}$ \\
\hline $\begin{array}{l}\text { Domestic Taxes on Goods \& Services } \\
\text { General Sales \& TT } \\
\text { Manufacturing } \\
\text { Non-Manufacturing } \\
\text { Imports }\end{array}$ & $\begin{array}{r}354 \\
39 \\
39\end{array}$ & $\begin{array}{r}384 \\
72 \\
72\end{array}$ & $\begin{array}{r}421 \\
79 \\
79\end{array}$ & $\begin{array}{l}494 \\
111 \\
111\end{array}$ & $\begin{array}{l}\mathbf{6 4 5} \\
\mathbf{2 4 7} \\
247\end{array}$ & $\begin{array}{l}786 \\
326 \\
326\end{array}$ & $\begin{array}{r}\mathbf{1 , 0 7 1} \\
\mathbf{3 9 4} \\
394\end{array}$ & $\begin{array}{r}\mathbf{1 , 1 9 1} \\
\mathbf{5 3 6} \\
457 \\
79 \\
-\end{array}$ & $\begin{array}{r}\mathbf{1 , 2 5 2} \\
\mathbf{6 0 4} \\
495 \\
109 \\
-\end{array}$ & $\begin{array}{r}\mathbf{1 , 3 7 5} \\
\mathbf{6 4 6} \\
531 \\
115 \\
-\end{array}$ & $\begin{array}{r}\mathbf{1 , 4 1 7} \\
\mathbf{7 1 1} \\
569 \\
142 \\
-\end{array}$ & $\begin{array}{r}\mathbf{1 , 5 4 8} \\
\mathbf{6 6 2} \\
451 \\
211 \\
-\end{array}$ & $\begin{array}{r}\mathbf{2 , 5 5 7} \\
\mathbf{1 , 0 7 8} \\
834 \\
244 \\
-\end{array}$ & $\begin{array}{r}\mathbf{2 , 9 6 6} \\
\mathbf{1 , 1 9 5} \\
665 \\
530 \\
-\end{array}$ & $\begin{array}{r}\mathbf{3 , 4 9 7} \\
\mathbf{1 , 6 3 9} \\
1,051 \\
588 \\
-\end{array}$ & $\begin{array}{l}\mathbf{4 , 8 6 4} \\
\mathbf{2 , 8 2 8} \\
1,727 \\
1,101\end{array}$ \\
\hline $\begin{array}{l}\text { Selective Sales (Excise) } \\
\text { Liquor } \\
\text { Tobacco } \\
\text { Other }\end{array}$ & 137 & 154 & 185 & 237 & 226 & 265 & $\begin{array}{r}336 \\
23 \\
313 \\
0\end{array}$ & $\begin{array}{r}368 \\
27 \\
341 \\
0\end{array}$ & $\begin{array}{r}\mathbf{5 8 9} \\
216 \\
373 \\
-\end{array}$ & $\begin{array}{r}\mathbf{6 6 5} \\
206 \\
459 \\
-\end{array}$ & $\begin{array}{r}\mathbf{6 4 2} \\
190 \\
452 \\
-\end{array}$ & 832 & $\begin{array}{r}\mathbf{1 , 3 7 4} \\
555 \\
759 \\
60\end{array}$ & $\begin{array}{r}\mathbf{1 , 6 8 4} \\
498 \\
801 \\
385\end{array}$ & $\begin{array}{r}1,776 \\
683 \\
1,000 \\
93\end{array}$ & $\begin{array}{r}1,941 \\
749 \\
1,123 \\
69\end{array}$ \\
\hline $\begin{array}{l}\text { Defence Levy } \\
\text { Licence Tax } \\
\text { Heavy Oil Motor Vehicle Tax } \\
\text { Surplus of Govt. Monopolies }\end{array}$ & $\begin{array}{r}- \\
40 \\
10 \\
118\end{array}$ & $\begin{array}{r}- \\
38 \\
0 \\
107\end{array}$ & $\begin{array}{r}3 \overline{1} \\
1 \\
110\end{array}$ & $\begin{array}{r}- \\
18 \\
0 \\
110\end{array}$ & $\begin{array}{r}- \\
47 \\
1 \\
124\end{array}$ & $\begin{array}{r}- \\
4 \overline{5} \\
1 \\
149\end{array}$ & $\begin{array}{r}- \\
53 \\
0 \\
287\end{array}$ & $\begin{array}{r}- \\
50 \\
7 \\
230\end{array}$ & $\begin{array}{r}- \\
59 \\
0 \\
0\end{array}$ & $\begin{array}{r}- \\
64 \\
0 \\
-\end{array}$ & $\begin{array}{r}- \\
64 \\
0 \\
-\end{array}$ & $\begin{array}{r}- \\
54 \\
0 \\
-\end{array}$ & $\begin{array}{r}- \\
74 \\
0 \\
31\end{array}$ & $\begin{array}{r}- \\
87 \\
- \\
-\end{array}$ & $\begin{array}{r}8 \\
1 \\
1 \\
-\end{array}$ & $\begin{array}{r}- \\
95 \\
- \\
-\end{array}$ \\
\hline $\begin{array}{l}\text { Taxes on Specific Services } \\
\text { Betting/Lottery Tax }\end{array}$ & $\begin{array}{l}\mathbf{1 0} \\
10\end{array}$ & $\begin{array}{l}\mathbf{1 2} \\
12\end{array}$ & $\begin{array}{l}\mathbf{1 5} \\
15\end{array}$ & $\begin{array}{l}\mathbf{1 8} \\
18\end{array}$ & $\begin{array}{l}\mathbf{0} \\
0\end{array}$ & $\begin{array}{l}\mathbf{0} \\
0\end{array}$ & $\begin{array}{l}\mathbf{0} \\
0\end{array}$ & $\begin{array}{l}\mathbf{0} \\
0\end{array}$ & $\begin{array}{l}\mathbf{0} \\
0\end{array}$ & $\begin{array}{l}\mathbf{0} \\
0\end{array}$ & $\begin{array}{l}\mathbf{0} \\
0\end{array}$ & $\begin{array}{l}\mathbf{0} \\
0\end{array}$ & $\begin{array}{l}\mathbf{0} \\
0\end{array}$ & $\begin{array}{l}- \\
-\end{array}$ & $\begin{array}{l}\mathbf{0} \\
0\end{array}$ & \\
\hline $\begin{array}{l}\text { Taxes on International Trade } \\
\text { Import Duties } \\
\text { Export Duties } \\
\text { Foreign Exchange Taxes } \\
\text { FEECs Revenue }\end{array}$ & $\begin{array}{r}736 \\
477 \\
259 \\
0 \\
-\end{array}$ & $\begin{array}{r}777 \\
544 \\
233 \\
0 \\
-\end{array}$ & $\begin{array}{r}912 \\
514 \\
321 \\
- \\
77\end{array}$ & $\begin{array}{r}\mathbf{1 , 0 9 1} \\
460 \\
346 \\
- \\
285\end{array}$ & $\begin{array}{r}\mathbf{1 , 1 2 1} \\
306 \\
369 \\
- \\
446\end{array}$ & $\begin{array}{r}981 \\
282 \\
303 \\
- \\
396\end{array}$ & $\begin{array}{r}\mathbf{1 , 0 7 1} \\
258 \\
277 \\
- \\
536\end{array}$ & $\begin{array}{r}1,321 \\
222 \\
425 \\
- \\
674\end{array}$ & $\begin{array}{r}\mathbf{2 , 0 6 2} \\
277 \\
821 \\
- \\
964\end{array}$ & $\begin{array}{r}\mathbf{1 , 9 8 7} \\
336 \\
596 \\
- \\
1,055\end{array}$ & $\begin{array}{r}\mathbf{2 , 3 2 1} \\
476 \\
771 \\
- \\
1,074\end{array}$ & $\begin{array}{r}\mathbf{2 , 8 7 0} \\
518 \\
1,195 \\
- \\
1,157\end{array}$ & $\begin{array}{r}\mathbf{6 , 4 8 4} \\
1,409 \\
4,746 \\
- \\
329\end{array}$ & $\begin{array}{r}\mathbf{6 , 5 2 9} \\
2,131 \\
4,391 \\
- \\
7\end{array}$ & $\begin{array}{r}\mathbf{6 , 3 1 7} \\
2,576 \\
3,740 \\
- \\
1\end{array}$ & $\begin{array}{r}\mathbf{6 , 5 1 8} \\
2,725 \\
3,771 \\
- \\
22\end{array}$ \\
\hline $\begin{array}{l}\text { Taxes on Property } \\
\text { Estate Duties } \\
\text { Wealth Tax / Gift Tax } \\
\text { Taxes on Financial \& Cap. Trans. } \\
\text { Treasury Bill Tax } \\
\text { Property Transfer Tax } \\
\text { Bank Debits Tax }\end{array}$ & $\begin{array}{r}24 \\
10 \\
12 \\
2 \\
- \\
0 \\
2\end{array}$ & $\begin{array}{r}22 \\
9 \\
13 \\
0 \\
- \\
0 \\
-\end{array}$ & $\begin{array}{r}23 \\
9 \\
13 \\
1 \\
- \\
1 \\
-\end{array}$ & $\begin{array}{r}28 \\
14 \\
13 \\
1 \\
- \\
1 \\
-\end{array}$ & $\begin{array}{r}30 \\
12 \\
17 \\
1 \\
- \\
1 \\
-\end{array}$ & $\begin{array}{r}55 \\
14 \\
25 \\
16 \\
- \\
1 \\
15\end{array}$ & $\begin{array}{r}62 \\
16 \\
27 \\
19 \\
- \\
3 \\
16\end{array}$ & $\begin{array}{r}86 \\
14 \\
41 \\
31 \\
- \\
2 \\
29\end{array}$ & $\begin{array}{r}81 \\
11 \\
37 \\
33 \\
- \\
2 \\
31\end{array}$ & $\begin{array}{r}102 \\
11 \\
54 \\
37 \\
- \\
3 \\
34\end{array}$ & $\begin{array}{r}100 \\
14 \\
45 \\
41 \\
- \\
3 \\
38\end{array}$ & $\begin{array}{r}118 \\
18 \\
50 \\
50 \\
- \\
1 \\
49\end{array}$ & $\begin{array}{r}142 \\
18 \\
45 \\
79 \\
- \\
10 \\
69\end{array}$ & $\begin{array}{r}62 \\
15 \\
37 \\
10 \\
- \\
10 \\
-\end{array}$ & $\begin{array}{r}56 \\
16 \\
28 \\
12 \\
- \\
12 \\
0\end{array}$ & $\begin{array}{r}71 \\
24 \\
37 \\
10 \\
- \\
10 \\
-\end{array}$ \\
\hline $\begin{array}{l}\text { Other Taxes } \\
\text { o/w Stamp Taxes }\end{array}$ & $\begin{array}{l}16 \\
16\end{array}$ & $\begin{array}{l}19 \\
19\end{array}$ & $\begin{array}{l}20 \\
20\end{array}$ & $\begin{array}{l}21 \\
21\end{array}$ & $\begin{array}{l}21 \\
21\end{array}$ & $\begin{array}{l}21 \\
21\end{array}$ & $\begin{array}{l}25 \\
25\end{array}$ & $\begin{array}{l}20 \\
20\end{array}$ & $\begin{array}{l}19 \\
19\end{array}$ & $\begin{array}{l}25 \\
25\end{array}$ & $\begin{array}{l}26 \\
26\end{array}$ & $\begin{array}{l}36 \\
36\end{array}$ & $\begin{array}{l}68 \\
68\end{array}$ & $\begin{array}{l}101 \\
101\end{array}$ & $\begin{array}{l}201 \\
201\end{array}$ & $\begin{array}{l}211 \\
211\end{array}$ \\
\hline Tax Revenue & 1,412 & 1,515 & 1,697 & 1,983 & 2,262 & 2,290 & 2,682 & $\mathbf{3 , 3 2 3}$ & 4,020 & 4,259 & 4,799 & 5,509 & 10,354 & 11,015 & 12,158 & 13,694 \\
\hline
\end{tabular}


Tax Revenue

Appendix 1 (Contd.)

\begin{tabular}{|c|c|c|c|c|c|c|c|c|c|c|c|c|c|c|c|}
\hline \multicolumn{16}{|c|}{ (Rs. Million) } \\
\hline Tax Category & 82 & 83 & 84 & 85 & 86 & 87 & 88 & 89 & 90 & 91 & 92 & 93 & 94 & 95 & 96 \\
\hline Tax on Income, Profit \& Cap. Gains & 2,923 & 3,366 & 5,480 & 5,586 & 4,787 & 4,909 & 4,647 & 5,148 & 7,337 & 9,722 & 10,967 & 12,543 & 15,277 & 17,161 & 20,751 \\
\hline Personal & 808 & 891 & 1,760 & 1,424 & 1,513 & 1,580 & 1,464 & 2,207 & 2,957 & 3,539 & 4,067 & 5,235 & 5,621 & 7,358 & 7,315 \\
\hline Corporate & 2,115 & 2,475 & 3,720 & 4,162 & 3,274 & 3,329 & 3,183 & 2,941 & 4,380 & 6,183 & 6,900 & 7,308 & 9,656 & 9,803 & 13,436 \\
\hline Domestic Taxes on Goods \& Services & 6,320 & 8,710 & 10,888 & 13,360 & 14,788 & 15,668 & 17,021 & 20,829 & 28,771 & 32,110 & 38,160 & 47,963 & 56,685 & $\mathbf{7 0 , 7 9 7}$ & 77,105 \\
\hline General Sales \& TT & 4,052 & 6,224 & 8,143 & 10,189 & 10,088 & 10,611 & 12,321 & 14,658 & 20,291 & 21,430 & 24,095 & 29,663 & 32,300 & $\mathbf{3 6 , 4 2 9}$ & 37,631 \\
\hline Manufacturing & 1,806 & 2,718 & 3,045 & 3,619 & 3,270 & 3,675 & 3,610 & 4,496 & 6,798 & 7,945 & 8,262 & 9,231 & 9,171 & 9,906 & 8,874 \\
\hline Non-Manufacturing & 1,524 & 1,891 & 1,928 & 2,739 & 2,415 & 2,426 & 3,386 & 3,004 & 3,726 & 2,974 & 3,546 & 4,825 & 6,445 & 7,074 & 9,711 \\
\hline Imports & 722 & 1,615 & 3,170 & 3,831 & 4,403 & 4,510 & 5,325 & 7,158 & 9,767 & 10,511 & 12,287 & 15,607 & 16,684 & 19,449 & 19,046 \\
\hline Selective Sales (Excise) & 2,123 & 2,298 & 2,549 & 2,982 & 4,414 & 4,716 & 4,420 & 5,812 & 8,170 & 10,597 & 10,232 & 11,655 & 14,632 & 19,436 & 22,067 \\
\hline Liquor & 808 & 867 & 1,013 & 1,104 & 1,485 & 1,644 & 1,754 & 1,955 & 2,657 & 3,126 & 3,434 & 4,063 & 4,686 & 6,298 & 5,839 \\
\hline Tobacco & 1,315 & 1,431 & 1,536 & 1,877 & 2,927 & 3,071 & 2,665 & 3,855 & 5,461 & 6,884 & 3,339 & 6,866 & 7,888 & 8,788 & 12,833 \\
\hline Other & - & - & - & 1 & 2 & 1 & 1 & 2 & 52 & 587 & 3,459 & 726 & 2,058 & 4,350 & 3,395 \\
\hline Defence Levy & - & _- & - & - & - & _- & - & _- & _- & - & 3,763 & 6,589 & 9,693 & 14,408 & 16,441 \\
\hline Licence Tax & 145 & 188 & 194 & 188 & 285 & 340 & 279 & 358 & 309 & 80 & 66 & 56 & 60 & 524 & 966 \\
\hline Heavy Oil Motor Vehicle Tax & 0 & 0 & 0 & 0 & 0 & 0 & - & - & 0 & - & - & - & - & - & - \\
\hline Surplus of Govt. Monopolies & - & - & - & - & - & - & - & - & - & - & - & - & - & - & - \\
\hline Taxes on Specific Services & 0 & 0 & 2 & 1 & 1 & 1 & 1 & 1 & 1 & 3 & 4 & - & - & - & _ \\
\hline Betting/Lottery Tax & 0 & 0 & 2 & 1 & 1 & 1 & 1 & 1 & 1 & 3 & 4 & - & - & - & - \\
\hline Taxes on International Trade & 5,172 & 7,439 & 13,081 & 10,998 & 11,050 & 12,975 & 12,501 & 16,495 & 19,341 & 19,752 & 21,641 & 20,819 & 22,598 & 24,373 & 25,464 \\
\hline Import Duties & 2,538 & 4,047 & 6,670 & 8,093 & 9,414 & 11,051 & 10,671 & 14,923 & 16,792 & 18,617 & 20,819 & 20,762 & 22,598 & 24,365 & 25,459 \\
\hline Export Duties & 2,634 & 3,392 & 6,411 & 2,905 & 1,636 & 1,924 & 1,830 & 1,572 & 2,549 & 1,135 & 822 & 57 & - & 8 & 5 \\
\hline Foreign Exchange Taxes & - & - & - & - & - & - & - & - & - & - & - & - & - & - & - \\
\hline FEECs Revenue & 0 & 0 & 0 & 0 & - & - & - & - & - & - & - & - & - & - & - \\
\hline Taxes on Property & 74 & 69 & 92 & 123 & 154 & 112 & 114 & 2,470 & 2,815 & 3,222 & 2,185 & 1,095 & 504 & 1,050 & 1,604 \\
\hline Estate Duties & 22 & 17 & 23 & 41 & 34 & 25 & 19 & 10 & 17 & 13 & 15 & - & - & - & - \\
\hline Wealth Tax / Gift Tax & 42 & 43 & 59 & 69 & 108 & 75 & 80 & 100 & 163 & 161 & 161 & - & - & - & - \\
\hline Taxes on Financial \& Cap. Trans. & 10 & 9 & 10 & 13 & 12 & 12 & 15 & 2,360 & 2,635 & 3,048 & 2,009 & 1,095 & 504 & 1,050 & 1,604 \\
\hline Treasury Bill Tax & - & - & - & - & - & - & - & 2,345 & 2,618 & 3,033 & 1,991 & 1,073 & 471 & 1,050 & 1,604 \\
\hline Property Transfer Tax & 10 & 9 & 10 & 13 & 12 & 12 & 15 & 15 & 17 & 15 & 18 & 22 & 33 & - & - \\
\hline Bank Debits Tax & - & - & - & - & - & - & - & - & - & - & - & - & - & - & - \\
\hline Other Taxes & 247 & 326 & 397 & & 492 & 1,454 & 1,663 & 2,571 & 2,942 & 3,351 & 3,400 & 3,452 & 4,363 & 5,150 & 5,279 \\
\hline o/w Stamp Taxes & 247 & 326 & 397 & 375 & 492 & 1,454 & 1,663 & 2,351 & 2,942 & 3,271 & 3,400 & 3,452 & 4,363 & 5,150 & 5,279 \\
\hline Tax Revenue & 14,736 & 19,911 & 29,938 & 30,442 & 31,271 & 35,118 & 35,946 & 47,513 & 61,206 & 68,157 & 76,353 & 85,872 & 99,4271 & 118,5311 & 30,203 \\
\hline
\end{tabular}



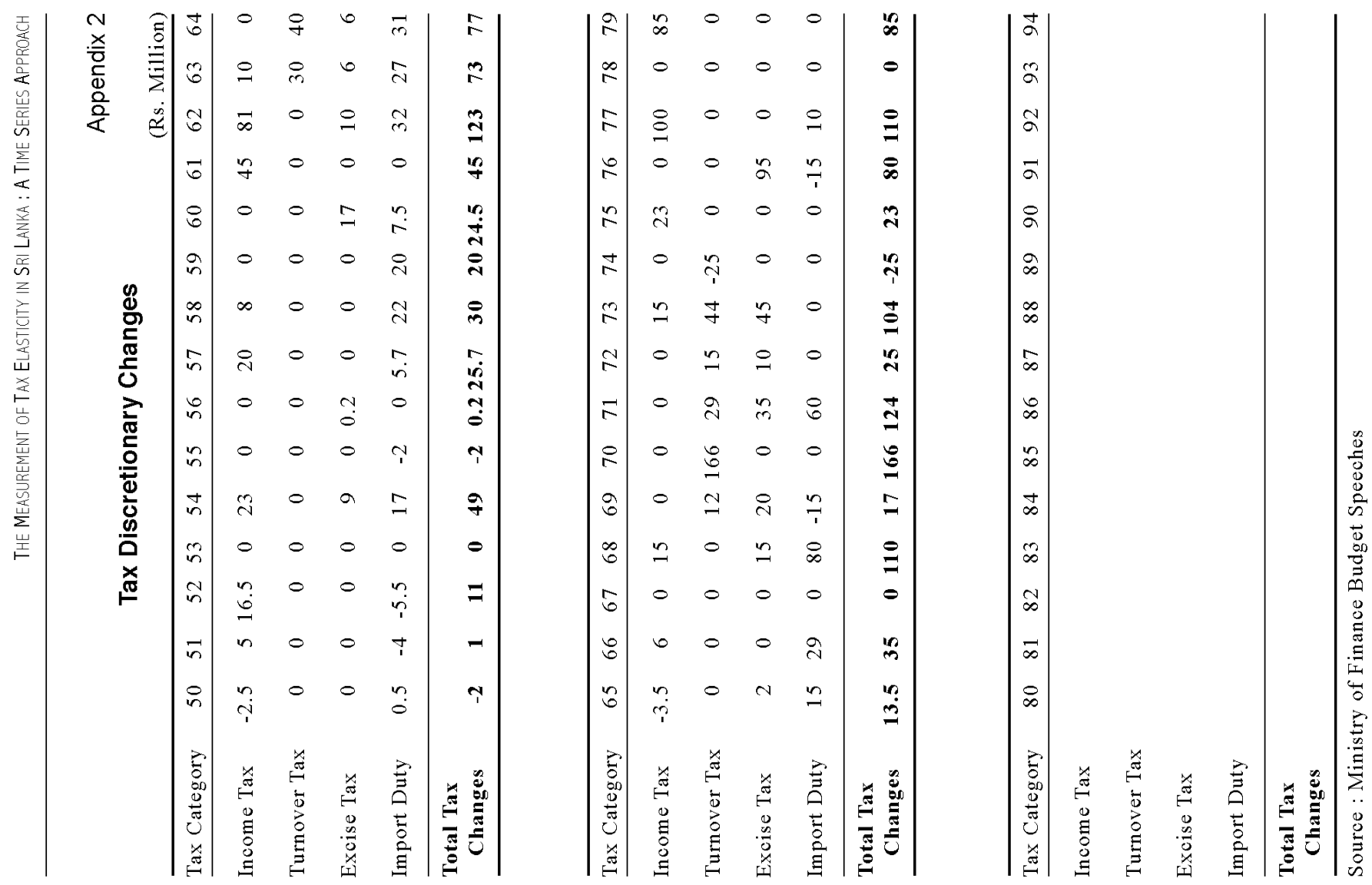


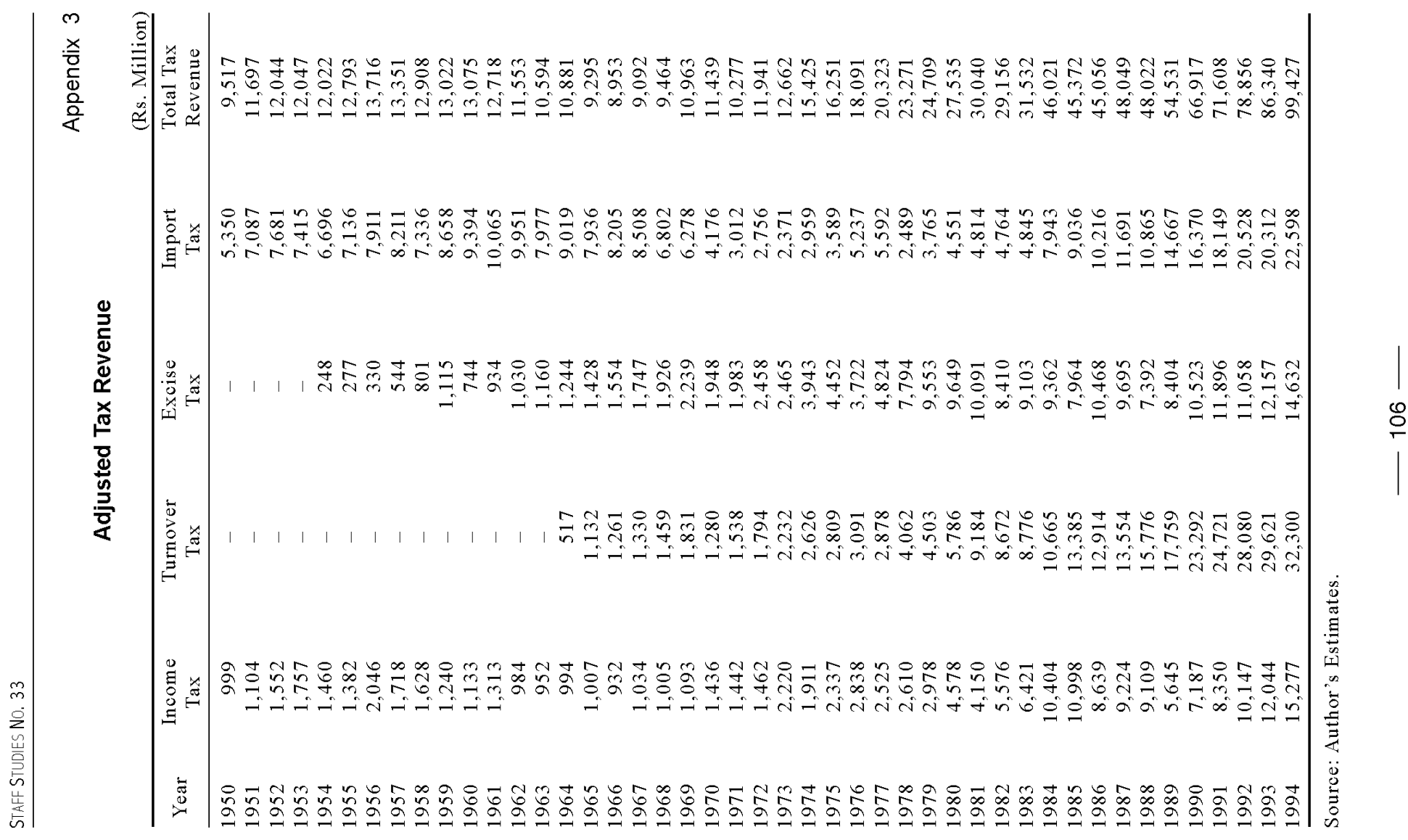


Ratios of Actual to Estimated Tax

Appendix 4

\begin{tabular}{|c|c|c|c|c|c|c|c|c|c|c|c|c|c|c|c|}
\hline Tax Category & $49 / 50$ & $50 / 51$ & $51 / 52$ & $52 / 53$ & $53 / 54$ & $54 / 55$ & $55 / 56$ & $56 / 57$ & $57 / 58$ & $58 / 59$ & $59 / 60$ & $60 / 61$ & $61 / 62$ & $62 / 63$ & $63 / 64$ \\
\hline Tax on Income, Profit & 1.0 & 1.0 & 1.0 & 1.0 & 1.0 & 0.9 & 1.0 & 1.0 & 0.9 & 0.9 & 1.0 & 1.2 & 0.9 & 0.9 & 1.1 \\
\hline Domestic Taxes on Goods \& Services & 1.0 & 0.8 & 1.0 & 1.1 & 0.9 & 1.0 & 1.0 & 1.1 & 1.2 & 1.1 & 1.1 & 1.0 & 1.0 & 1.1 & 1.0 \\
\hline General Sales \& TT & 0.0 & 0.0 & 0.0 & 0.0 & 0.0 & 0.0 & 0.0 & 0.0 & 0.0 & 0.0 & 0.0 & 0.0 & 0.0 & 0.0 & 1.0 \\
\hline Selective Sales (Excise) & 1.1 & 1.2 & 1.0 & 1.2 & 1.1 & 1.1 & 1.0 & 1.5 & 1.4 & 1.2 & 1.0 & 1.1 & 1.0 & 1.2 & 1.0 \\
\hline Defence Levy & 0.0 & 0.0 & 0.0 & 0.0 & 0.0 & 0.0 & 0.0 & 0.0 & 0.0 & 0.0 & 0.0 & 0.0 & 0.0 & 0.0 & 0.0 \\
\hline Licence Tax & 1.0 & 1.0 & 1.0 & 1.1 & 0.7 & 1.1 & 1.0 & 1.0 & 1.7 & 1.2 & 1.4 & 0.8 & 0.9 & 0.9 & 1.1 \\
\hline Motor Vehicle Taxes & 1.0 & 1.7 & 1.8 & 2.2 & 1.0 & 1.0 & 1.0 & 1.3 & 0.8 & 0.8 & 0.4 & 1.0 & 1.1 & 1.1 & 0.8 \\
\hline Surplus of Govt. Monopolies & 0.9 & 0.7 & 1.0 & 1.1 & 1.0 & 0.9 & 1.0 & 1.0 & 1.0 & 1.1 & 1.0 & 1.0 & 1.0 & 1.0 & 1.1 \\
\hline Taxes on Specific Services & 1.0 & 1.3 & 1.3 & 0.8 & 1.7 & 1.0 & 0.9 & 0.8 & 0.6 & 0.7 & 0.8 & 0.9 & 0.7 & 1.2 & 1.0 \\
\hline Lottery Tax & 1.0 & 1.3 & 1.3 & 0.8 & 1.7 & 1.0 & 0.9 & 0.8 & 0.6 & 0.7 & 0.8 & 0.9 & 0.7 & 1.2 & 1.0 \\
\hline Taxes on International Trade & 1.1 & 1.0 & 1.0 & 1.1 & 1.1 & 1.0 & 1.1 & 1.0 & 1.0 & 1.0 & 1.0 & 1.0 & 1.1 & 0.9 & 1.0 \\
\hline Import Duties & 1.0 & 1.0 & 1.0 & 1.0 & 1.0 & 1.0 & 1.1 & 1.1 & 1.0 & 1.1 & 1.0 & 1.0 & 1.1 & 0.9 & 1.0 \\
\hline Export Duties & 1.1 & 1.0 & 1.0 & 1.1 & 1.1 & 1.0 & 1.0 & 1.0 & 1.0 & 0.9 & 1.0 & 1.0 & 1.0 & 0.9 & 0.9 \\
\hline FEECs Revenue & 0.0 & 0.0 & 0.0 & 0.0 & 0.0 & 0.0 & 0.0 & 0.0 & 0.0 & 0.0 & 0.0 & 0.0 & 0.0 & 0.0 & 0.0 \\
\hline Taxes on Property & 1.0 & 1.0 & 2.0 & 1.3 & 1.2 & 1.4 & 0.9 & 0.4 & 0.8 & 0.8 & 1.1 & 0.8 & 0.9 & 1.1 & 0.9 \\
\hline Estate Duties & 1.0 & 1.0 & 2.0 & 1.3 & 1.2 & 1.4 & 0.9 & 0.4 & 0.7 & 1.0 & 1.1 & 1.0 & 1.3 & 1.1 & 1.1 \\
\hline Wealth Tax / Gift Tax & 0.0 & 0.0 & 0.0 & 0.0 & 0.0 & 0.0 & 0.0 & 0.0 & 0.0 & 0.0 & 1.0 & 1.0 & 0.9 & 1.0 & 0.7 \\
\hline Taxes on Financial \& Cap. Trans. & 0.0 & 0.0 & 0.0 & 0.0 & 0.0 & 0.0 & 0.0 & 0.0 & 0.9 & 0.8 & 1.0 & 0.6 & 0.8 & 1.1 & 1.1 \\
\hline Treasury Bill Tax & 0.0 & 0.0 & 0.0 & 0.0 & 0.0 & 0.0 & 0.0 & 0.0 & 0.0 & 0.0 & 0.0 & 0.0 & 0.0 & 0.0 & 0.0 \\
\hline Property Transfer Tax & 0.0 & 0.0 & 0.0 & 0.0 & 0.0 & 0.0 & 0.0 & 0.0 & 0.0 & 0.0 & 0.0 & 0.0 & 0.0 & 0.0 & 0.0 \\
\hline Other Taxes & 1.1 & 1.4 & 1.1 & 1.2 & 1.0 & 1.0 & 1.1 & 1.1 & 0.5 & 0.8 & 1.1 & 1.0 & 1.1 & 1.2 & 1.2 \\
\hline Stamp Taxes & 1.1 & 1.4 & 1.1 & 1.2 & 1.0 & 1.0 & 1.1 & 1.1 & 0.5 & 0.8 & 1.1 & 1.0 & 1.1 & 1.2 & 1.2 \\
\hline Total Taxes & 1.0 & 1.0 & 1.0 & 1.1 & 1.0 & 1.0 & 1.0 & 1.0 & 1.0 & 1.0 & 1.0 & 1.0 & 1.0 & 0.9 & 1.0 \\
\hline
\end{tabular}


Ratios of Actual to Estimated Tax

Appendix 4 (Contd.)

\begin{tabular}{|c|c|c|c|c|c|c|c|c|c|c|c|c|c|c|c|}
\hline Tax Category & $64 / 65$ & $65 / 66$ & $66 / 67$ & $67 / 68$ & $68 / 69$ & $69 / 70$ & $70 / 71$ & $71 / 72$ & 73 & 74 & 75 & 76 & 77 & 78 & 79 \\
\hline Tax on Income, Profit & 1.1 & 1.1 & 1.2 & 1.2 & 1.0 & 1.0 & 1.0 & 0.7 & 1.1 & 1.1 & 1.3 & 1.1 & 1.1 & 1.0 & 1.2 \\
\hline Domestic Taxes on Goods \& Services & 1.1 & 1.1 & 1.0 & 1.0 & 1.0 & 1.0 & 1.0 & 0.9 & 1.0 & 1.0 & 1.0 & 0.9 & 1.0 & 1.0 & 1.0 \\
\hline General Sales \& TT & 1.0 & 1.1 & 1.0 & 1.1 & 1.0 & 1.0 & 1.0 & 0.9 & 1.0 & 1.1 & 1.0 & 1.0 & 1.0 & 1.0 & 0.9 \\
\hline Selective Sales (Excise) & 1.0 & 1.0 & 1.0 & 1.0 & 1.1 & 1.0 & 1.0 & 0.8 & 1.1 & 1.0 & 1.0 & 0.9 & 1.0 & 1.0 & 1.1 \\
\hline Defence Levy & 0.0 & 0.0 & 0.0 & 0.0 & 0.0 & 0.0 & 0.0 & 0.0 & 0.0 & 0.0 & 0.0 & 0.0 & 0.0 & 0.0 & 0.0 \\
\hline Licence Tax & 1.0 & 1.0 & 1.1 & 0.9 & 0.4 & 1.2 & 1.0 & 0.9 & 0.8 & 1.0 & 1.0 & 1.1 & 0.9 & 1.3 & 0.9 \\
\hline Surplus of Govt. Monopolies & 1.1 & 1.1 & 1.0 & 1.0 & 1.0 & 1.0 & 1.0 & 0.9 & 1.0 & 0.0 & 0.0 & 0.0 & 0.0 & 0.0 & 0.0 \\
\hline Taxes on Specific Services & 29.5 & 0.9 & 24.8 & 1.1 & 1.0 & 0.0 & 5.0 & 3.8 & 1.0 & 0.7 & 1.4 & 1.6 & 1.1 & 0.9 & 0.0 \\
\hline Lottery Tax & 29.5 & 0.9 & 24.8 & 1.1 & 1.0 & 0.0 & 5.0 & 3.8 & 1.0 & 0.7 & 1.4 & 1.6 & 1.1 & 0.9 & 0.0 \\
\hline Taxes on International Trade & 0.9 & 0.9 & 1.1 & 1.1 & 1.0 & 1.0 & 1.0 & 0.8 & 0.9 & 1.1 & 1.0 & 1.1 & 1.1 & 1.0 & 1.0 \\
\hline Import Duties & 0.8 & 0.9 & 1.1 & 1.0 & 1.0 & 1.0 & 1.0 & 0.8 & 0.9 & 1.3 & 1.1 & 1.0 & 1.0 & 1.0 & 1.1 \\
\hline Export Duties & 1.1 & 0.9 & 1.0 & 1.0 & 1.1 & 1.0 & 1.0 & 0.8 & 1.1 & 1.0 & 1.1 & 1.3 & 1.7 & 1.0 & 1.0 \\
\hline FEECs Revenue & 0.0 & 0.0 & 0.0 & 0.0 & 1.0 & 1.0 & 1.0 & 1.0 & 1.0 & 1.0 & 1.0 & 1.0 & 1.0 & 1.0 & 0.0 \\
\hline
\end{tabular}

\section{Taxes on Property}

Estate Duties

Wealth Tax / Gift Tax

Taxes on Financial \& Cap. Trans.

Treasury Bill Tax

Property Transfer Tax

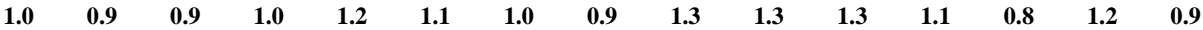

Other Taxes

Stamp Taxes

$\begin{array}{llllll}0.8 & 1.1 & 1.0 & 1.0 & 1.6 & 0.8\end{array}$

$\begin{array}{lllll}1.1 & 0.6 & 0.8 & 1.0\end{array}$

$\begin{array}{lllll}1.0 & 29.6 & 1.4 & 1.2 & 1.0\end{array}$

$\begin{array}{lllll}0.0 & 0.0 & 0.0 & 0.0 & 0.0\end{array}$

$\begin{array}{lllll}0.7 & 3.9 & 1.4 & 1.2 & 1.0\end{array}$

$1.4 \quad 1.0$

$0.9 \quad 0.9$

$\begin{array}{ll}0.9 & 0.9 \\ 0.0 & 0.0\end{array}$

$\begin{array}{lll}1.0 & 1.5 & 2.0\end{array}$

$\begin{array}{lll}0.7 & 1.1 & 1.1\end{array}$

$\begin{array}{lll}0.7 & 1.1 & 1.1 \\ 0.0 & 0.0 & 0.0\end{array}$

Total Taxes

0.9

$\begin{array}{lllll}1.0 & 1.0 & 1.1 & 1.1\end{array}$


Ratios of Actual to Estimated Tax

Appendix 4 (Contd.)

\begin{tabular}{|c|c|c|c|c|c|c|c|c|c|c|c|c|c|c|c|}
\hline Tax Category & 80 & 81 & 82 & 83 & 84 & 85 & 86 & 87 & 88 & 89 & 90 & 91 & 92 & 93 & 94 \\
\hline Tax on Income, Profit & 1.8 & 0.9 & 1.0 & 1.0 & 1.2 & 1.0 & 1.0 & 1.0 & 1.0 & 0.9 & 1.1 & 1.2 & 1.1 & 0.9 & 1.0 \\
\hline Domestic Taxes on Goods \& Services & 1.1 & 1.0 & 1.0 & 1.0 & 1.0 & 1.0 & 1.0 & 1.0 & 1.0 & 1.0 & $\mathbf{1 . 0}$ & 1.0 & 0.9 & 1.0 & 1.0 \\
\hline General Sales \& TT & 1.2 & 1.0 & 1.0 & 1.0 & 1.0 & 1.0 & 1.0 & 0.9 & 1.0 & 1.0 & 1.0 & 1.0 & 1.0 & 1.0 & 0.9 \\
\hline Selective Sales (Excise) & 1.0 & 1.0 & 1.0 & 1.0 & 1.0 & 0.9 & 1.1 & 1.0 & 1.0 & 1.0 & 1.0 & 1.0 & 0.8 & 0.9 & 1.1 \\
\hline Defence Levy & 0.0 & 0.0 & 0.0 & 0.0 & 0.0 & 0.0 & 0.0 & 0.0 & 0.0 & 0.0 & 0.0 & 0.0 & 0.8 & 1.0 & 1.1 \\
\hline Licence Tax & 0.9 & 0.8 & 0.6 & 1.0 & 1.0 & 1.0 & 1.2 & 1.2 & 0.9 & 1.0 & 0.8 & 2.5 & 2.0 & 1.5 & 1.2 \\
\hline Motor Vehicle Taxes & 80.0 & 0.0 & 1.0 & 1.3 & 1.0 & 1.7 & 10.0 & 0.0 & 0.0 & 0.0 & 0.0 & 0.0 & 0.0 & 0.0 & 0.0 \\
\hline Surplus of Govt. Monopolies & 0.0 & 0.0 & 0.0 & 0.0 & 0.0 & 0.0 & 0.0 & 0.0 & 0.0 & 0.0 & 0.0 & 0.0 & 0.0 & 0.0 & 0.0 \\
\hline Taxes on Specific Services & 3.0 & 1.1 & 1.3 & 3.1 & 10.1 & 1.0 & 1.0 & 1.0 & 0.5 & 1.0 & 1.4 & 0.0 & 0.0 & 0.0 & 0.0 \\
\hline Lottery Tax & 3.0 & 1.1 & 1.3 & 3.1 & 10.1 & 1.0 & 1.0 & 1.0 & 0.5 & 1.0 & 1.4 & 0.0 & 0.0 & 0.0 & 0.0 \\
\hline Taxes on International Trade & $\mathbf{1 . 0}$ & 1.0 & 0.9 & 1.0 & 1.1 & 1.1 & 1.0 & 1.0 & 0.9 & 1.0 & 1.1 & 1.0 & 1.0 & 0.8 & 0.8 \\
\hline Import Duties & 1.2 & 0.9 & 0.8 & 0.9 & 1.2 & 1.1 & 0.9 & 1.0 & 0.9 & 1.0 & 1.0 & 1.0 & 1.0 & 0.8 & 0.8 \\
\hline Export Duties & 1.0 & 1.0 & 1.0 & 1.1 & 1.0 & 1.0 & 1.0 & 1.0 & 1.0 & 0.9 & 1.1 & 0.8 & 1.0 & 1.8 & 0.0 \\
\hline FEECs Revenue & 0.0 & 0.0 & 0.0 & 0.0 & 0.0 & 0.0 & 0.0 & 0.0 & 0.0 & 0.0 & 0.0 & 0.0 & 0.0 & 0.0 & 0.0 \\
\hline Taxes on Property & 0.8 & 1.2 & 1.3 & 0.8 & 1.2 & 1.9 & 2.2 & 1.3 & 1.3 & 1.0 & 0.9 & 1.0 & 1.2 & 0.8 & 0.9 \\
\hline Estate Duties & 0.8 & 1.6 & 1.4 & 0.8 & 1.2 & 2.4 & 1.5 & 1.7 & 1.0 & 1.0 & 1.1 & 1.3 & 1.5 & 0.0 & 0.0 \\
\hline Wealth Tax / Gift Tax & 0.9 & 1.1 & 1.3 & 0.8 & 1.3 & 1.8 & 3.0 & 1.3 & 1.5 & 1.6 & 1.6 & 1.5 & 10.7 & 0.0 & 0.0 \\
\hline Taxes on Financial \& Cap. Trans. & 0.8 & 0.9 & 0.9 & 1.0 & 1.0 & 1.3 & 1.0 & 1.0 & 1.1 & 1.0 & 0.9 & 1.0 & 1.1 & 0.8 & 0.9 \\
\hline Treasury Bill Tax & 0.0 & 0.0 & 0.0 & 0.0 & 0.0 & 0.0 & 0.0 & 0.0 & 0.0 & 1.0 & 0.9 & 1.0 & 1.1 & 0.7 & 0.9 \\
\hline Property Transfer Tax & 0.8 & 0.9 & 0.9 & 1.0 & 1.0 & 1.3 & 1.0 & 1.0 & 1.1 & 1.1 & 1.1 & 0.9 & 0.0 & 0.0 & 0.0 \\
\hline Other Taxes & 2.2 & 1.1 & 1.2 & 1.2 & 1.2 & 1.2 & 1.2 & 1.2 & 1.0 & 1.2 & 1.2 & 1.2 & 1.1 & 1.0 & 1.0 \\
\hline Stamp Taxes & 2.2 & 1.1 & 1.2 & 1.2 & 1.2 & 1.2 & 1.2 & 1.2 & 1.0 & 1.1 & 1.2 & 1.1 & 1.1 & 1.0 & 1.0 \\
\hline Total Taxes & 1.1 & 1.0 & 0.9 & 1.0 & 1.1 & 1.0 & 1.0 & 1.0 & 1.0 & 1.0 & 1.0 & 1.0 & 1.0 & 0.9 & 0.9 \\
\hline
\end{tabular}

Source : Central Bank of Sri Lanka Annual Reports and Ministry of Finance Estimates of Revenue and Expenditure 


\section{Time Plots for Variables in Elasticity Estimation}

Appendix 5
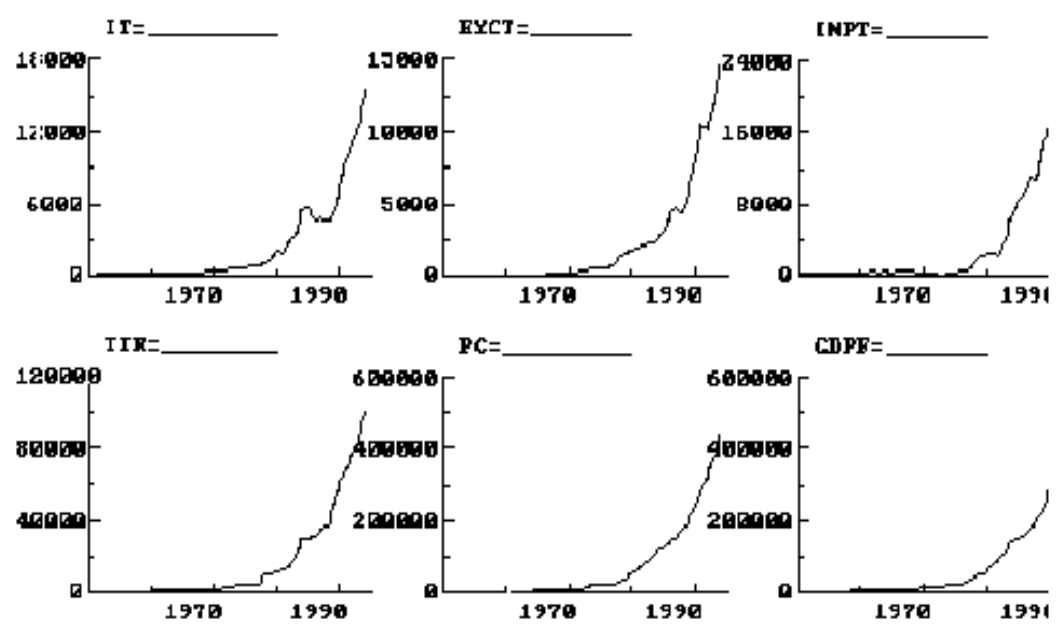

CDPF =

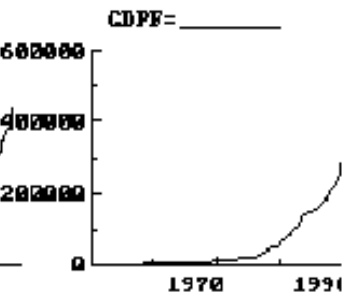

CDPV

IMP::

T T-
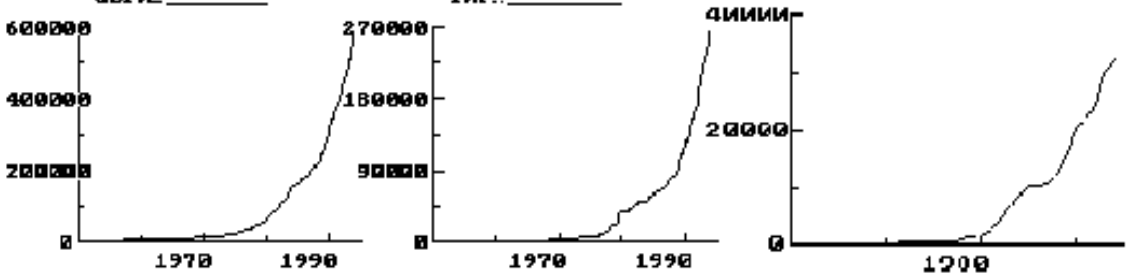

Source: Author's Estimates. 